\title{
Winter monsoon circulation of the northern Arabian Sea and Somali Current
}

\author{
Friedrich A. Schott and Jürgen Fischer \\ Institut für Meereskunde, Kiel, Germany
}

\begin{abstract}
The winter monsoon circulation in the northern inflow region of the Somali Current is discussed on the basis of an array of moored acoustic Doppler current profiler and current meter stations deployed during 1995-1996 and a ship survey carried out in January 1998. It is found that the westward inflow into the Somali Current regime occurs essentially south of $11^{\circ} \mathrm{N}$ and that this inflow bifurcates at the Somali coast, with the southward branch supplying the equatorward Somali Current and the northward one returning into the northwestern Arabian Sea. This northward branch partially supplies a shallow outflow through the Socotra Passage between the African continent and the banks of Socotra and partially feeds into eastward recirculation directly along the southern slopes of Socotra. Underneath this shallow surface flow, southwestward undercurrent flows are observed. Undercurrent inflow from the Gulf of Aden through the Socotra Passage occurs between 100 and $1000 \mathrm{~m}$, with its current core at 700-800 m, and is clearly marked by the Red Sea Water (RSW) salinity maximum. The observations suggest that the maximum RSW inflow out of the Gulf of Aden occurs during the winter monsoon season and uses the Socotra Passage as its main route into the Indian Ocean. Westward undercurrent inflow into the Somali Current regime is also observed south of Socotra, but this flow lacks the RSW salinity maximum. Off the Arabian peninsula, eastward boundary flow is observed in the upper $800 \mathrm{~m}$ with a compensating westward flow to the south. The observed circulation pattern is qualitatively compared with recent high-resolution numerical model studies and is found to be in basic agreement.
\end{abstract}

\section{Introduction}

Very few observations have been carried out during the Northeast Monsoon in the northern Somali Current regime and interior northern Arabian Sea. As is known from climatological ship drift data [e.g., Molinari et al., 1990], the near-equatorial surface circulation of the western Indian Ocean during November to February is characterized by the southward flowing Somali Current, which encounters the northward flowing East African Coast Current at $2^{\circ}-4^{\circ} \mathrm{S}$ and out of this confluence the eastward flowing South Equatorial Countercurrent emerges [Swallow et al., 1991]. However, the Somali Current in winter does not appear to follow the coast all the way from the Horn of Africa to south of the equator. Instead, there appears to be inflow into the coast in the $5^{\circ}-10^{\circ}$ latitude band with southward flow from there to beyond the equator and northward flow in the northern Somali Current regime [e.g., Schott et al., 1990; Molinari et al., 1990].

Copyright 2000 by the American Geophysical Union.

Paper number 1999JC900312.

0148-0227/00/1999JC900312\$09.00
At the eastern entry of the Arabian Sea the Monsoon Current south of Sri Lanka flows westward during the winter monsoon as the Northeast Monsoon Current (NMC) [Schott et al., 1994]. Their moored observations yielded a mean westward NMC transport of $11 \mathrm{~Sv}$, concentrated in the upper $100 \mathrm{~m}$ and within $\sim 100 \mathrm{~km}$ of the Sri Lanka topography. Where this current goes after passing the $80^{\circ} \mathrm{E}$ meridian is not clear. Ship drift data suggest a low-latitude westward continuation of the NMC but also northwestward flow along the Indian subcontinent [Swallow and Fieux, 1982; Molinari et al., 1990]. Water mass distributions [Wyrtki, 1971] support a throughflow of low-salinity Bay of Bengal Water into the Arabian Sea during this time period. Donguy and Meyers [1995], from the analysis of the World Ocean Circulation Experiment (WOCE) expendable bathythermograph (XBT) lines, also supported the existence of a westward low-latitude geostrophic flow as the extension of the NMC.

West of India, an anticyclonic circulation feature, the Laccadive High, exists in the late phase of the Northeast Monsoon and appears subsequently to begin propagating westward [Bruce et al., 1994]. Model studies suggest its origin to be remote forcing from the Bay of Bengal by coastal trapped waves, which in turn, radiate Rossby 


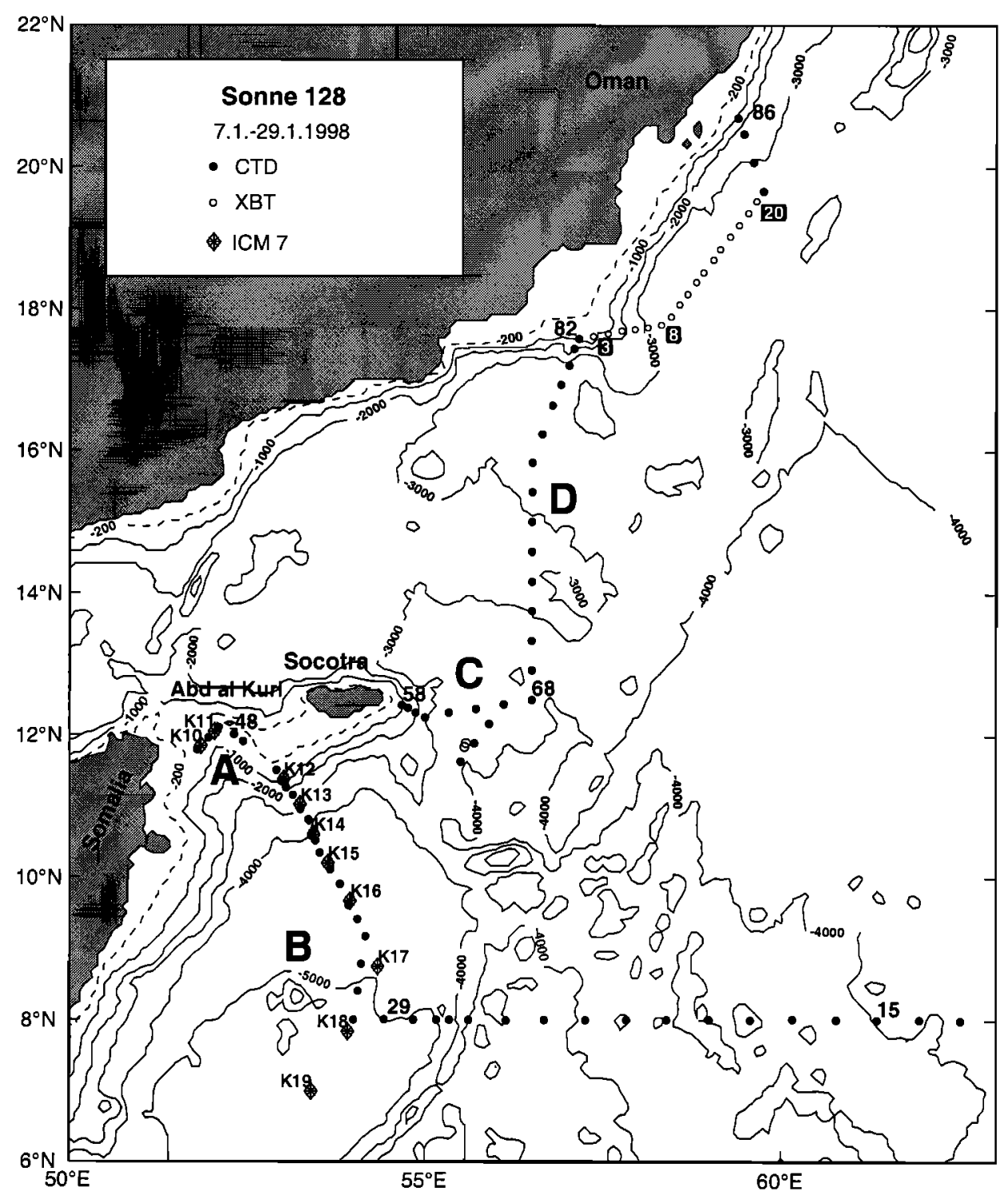

Figure 1. Topography of the Arabian Sea, positions of the moorings west and south of Socotra (diamonds), and ship track of R/V Sonne survey SO 128 of January 1998 marked by conductivitytemperature-depth (CTD) stations (solid circles) and expendable bathythermograph (XBTs) (open circles). Individual sections are labeled A-D for easier recognition in the text.

waves [e.g., McCreary et al., 1993; Shankar and Sheyte, 1997]. For the higher Arabian Sea latitudes Donguy and Meyers [1995] suggest a cycloncic circulation of order $10 \mathrm{~Sv}$ for the winter monsoon season, with eastward transport in the $4^{\circ}-8^{\circ} \mathrm{N}$ latitude range across the interior of the Arabian Sea and a corresponding westward inflow into the northern Somali Current regime. However, their XBT lines from Perth, Australia, to the Persian Gulf and to the Red Sea, respectively, leave a wide range of the interior Arabian Sea uncovered.

The subsurface structure of the Somali Current during the Northeast Monsoon also still poses several problems that require explanations. At the southern end the moored time series of Schott et al. [1990] showed a northward cross-equatorial undercurrent in winter underneath the shallow southward surface Somali Current, but the physical cause of this undercurrent and its connection to neighboring latitudes are still unclear. At $5^{\circ} \mathrm{N}$ the current structure in the moored observations of Quadfasel and Schott [1983] did not show such an undercurrent structure. For the $6^{\circ}-10^{\circ} \mathrm{N}$ latitude range Quadfasel and Schott [1983] derived a southward undercurrent underneath the northward flowing surface boundary current from analysis of earlier hydrographic observations. Offshore in the northern regime, where the Great Whirl spins around during the Southwest Monsoon [Swallow et al., 1983; Fischer et al., 1996; Schott et al., 1997], remnants of this large anticyclonic gyre may linger far into the winter monsoon season [Bruce et al., 1981] hidden underneath the developing near-surface winter monsoon circulation.

In this presentation the winter monsoon circulation 
of the northern Somali Current regime is discussed on the basis of two sets of observations: first, on a shipboard survey with $\mathrm{R} / \mathrm{V}$ Sonne with water mass and current profiling observations carried out in January 1998 and, second, on the records of the WOCE moored array ICM7 (Figure 1) placed in the offshore Somali Current, south of the island of Socotra, and in the passage between Socotra and the African mainland (called Socotra Passage in the following) during 1995-1996. The shipboard study covered the $8^{\circ} \mathrm{N}$ section by hydrography/tracer and acoustic Doppler current profiler (ADCP) observations from the Maldives westward to $53^{\circ} \mathrm{E}$ and then went on to investigate the area around Socotra, the Socotra Passage, and the meridional section from Socotra up to the Arabian peninsula (Figure 1).

For the interpretation of the observed current patterns we will also draw on recent model simulations based on forcing by realistic wind fields of the observational time period. We will mainly use output of the high-resolution Parallel Ocean Climate Model (POCM) of Semtner and Chervin [1992] as already analyzed for the Indian Ocean overturning circulation by Garternicht and Schott [1997]. We also inspected results of the multilayer reduced gravity model run by J. Kindle of the Naval Research Laboratory, Stennis Space Center, and of the Miami isopycnic model, run by O. Esenkov of Rosenstiel School of Marine and Atmospheric Sciences (RSMAS), University of Miami.

\section{Observations}

During April 1995 to October 1996 moored current observations were carried out across the northern Somali Current regime as part of WOCE. Because of the unresolved clearance situation for the Somali exclusive economic zone (EEZ), the array could not be deployed, as originally intended, normal to the coast and continental slope across the northern boundary current. Instead, a line of ADCP and current meter moorings was deployed on the continental slope south of the island of Socotra, with two moorings also covering the Socotra Passage located between the African continent and the island of Abd al Kuri (Figure 1). This passage, with a maximum depth of $\sim 1050 \mathrm{~m}$, had already been found to be crucial for the summer monsoon circulation in an earlier ship survey [Fischer et al., 1996]. It was found then, and subsequently confirmed, for the summer monsoon circulation of 1995 [Schott et al., 1997] that the exchange of the northern Somali Current with the interior Arabian Sea occurred dominantly through this passage and northward around Socotra rather than directly eastward in the $8^{\circ}-10^{\circ}$ latitude range.

The moored array was deployed during March 1995 by $\mathrm{R} / \mathrm{V}$ Meteor and retrieved by a chartered vessel in October 1996. The moorings along the $54^{\circ} \mathrm{E}$ line and the instrument coverage are shown in Figure 2. Six of the eight moorings along that line carried $150 \mathrm{kHz}$ AD-

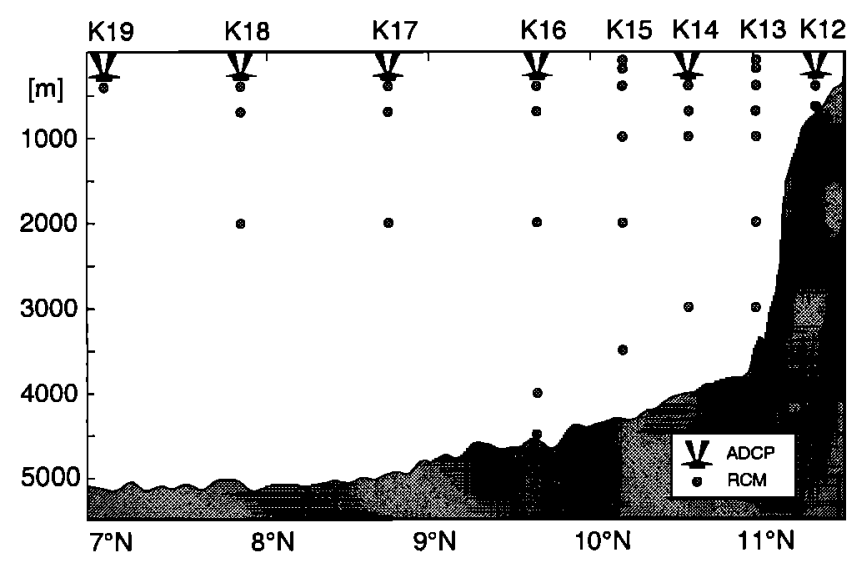

Figure 2. Topography along $54^{\circ} \mathrm{E}$ and current meter distribution on moorings K12-K19. Circles indicate positions of rotor current meters (RCMs) that yielded complete records over the winter 1995-1996 period, and acoustic Doppler current profilers (ADCPs) are shown by symbols with acoustic beams.

CPs on top, located at nominally $250 \mathrm{~m}$ depth, which all delivered good data. In the passage, mooring K10 on the western side also was equipped with an ADCP (Figure 3).

Besides ADCPs, conventional rotor current meters (RCMs) of type Aanderaa were used (Figure 2). The measurements from the ADCPs were interpolated to constant depths on the basis of backscatter distance measurements from the surface [Visbeck and Fischer, 1995], thus eliminating the mooring motion effects, while the depths of the RCM time series used in the following are their mean depths. The current observation level closest to the surface for all ADCPs that could be used was the $25 \mathrm{~m}$ level. The level above was contaminated because of interference by the direct sidelobe echos from the sea surface with the returns from the inclined main beams at shallower depths.

The shipboard observations on R/V Sonne consisted of conductivity-temperature-depth- $\mathrm{O}_{2}\left(\mathrm{CTDO}_{2}\right)$ measurements, current profiling by shipboard and lowered ADCP (LADCP), and, at five stations along the mooring line, current profiling by Pegasus profiler. For the determination of current vectors out of the shipboard ADCP registrations, a differential Global Positioning System (GPS) was used for position determination, and the Ashtech GPS antenna was used for improving the ship's heading.

For the current sections and transports in the following, the shipboard ADCP and LADCP currents were merged to a joint product and objectively interpolated with mapping scales that varied, according to station spacing, from 5 to $30 \mathrm{~km}$ and vertically from $20 \mathrm{~m}$ in the upper $300 \mathrm{~m}$ covered by the shipboard ADCP to $100 \mathrm{~m}$ at depth. The merged current profiles were corrected for barotropic tidal constituents. Along the mooring line and in the Socotra Passage these could 


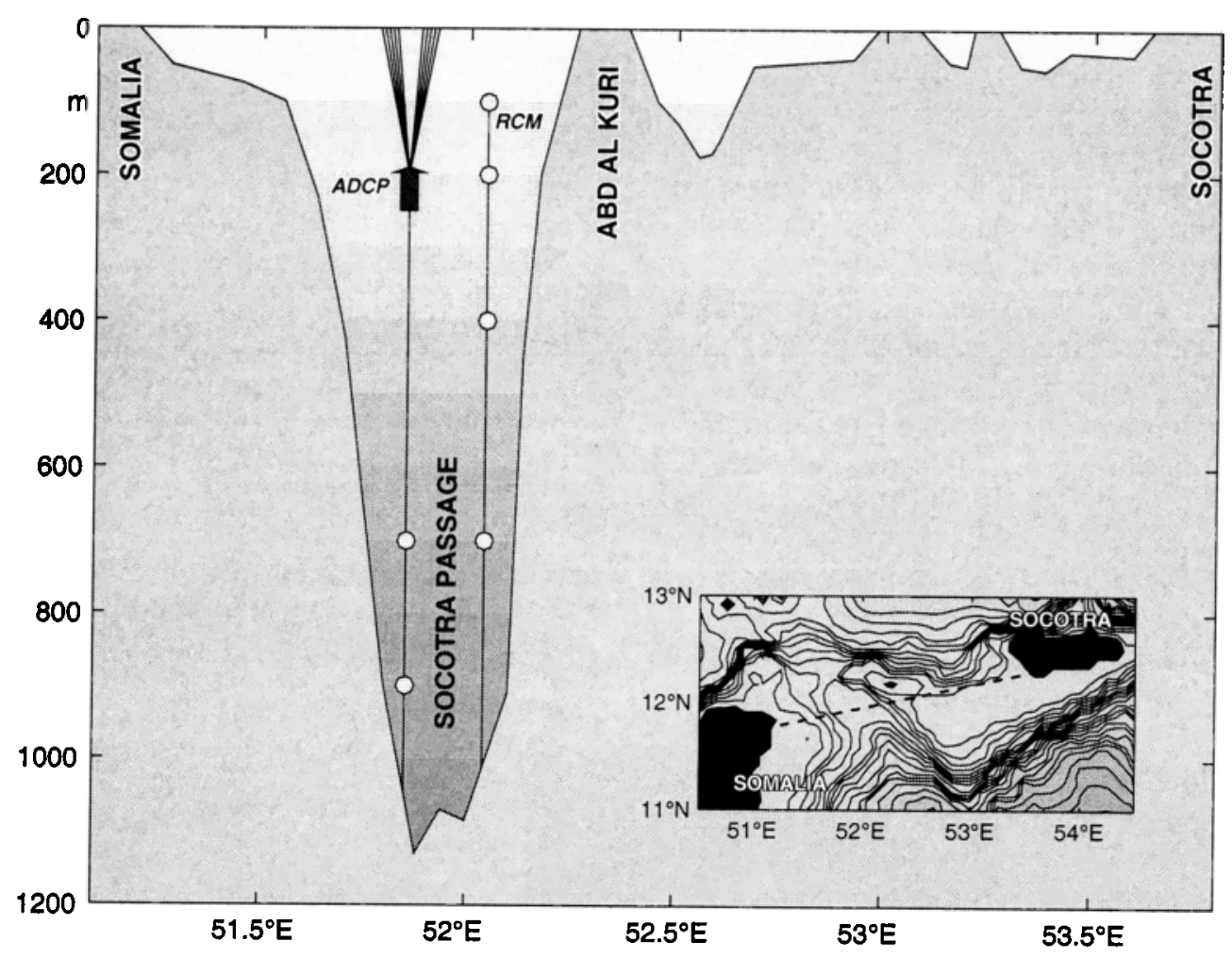

Figure 3. Topography of the islands of Socotra and Abd al Kuri and the Socotra Passage with instrument distributions on passage moorings K10 and K11 (see inset for location of section).

be determined from the moored current records ( $M$. Dengler, personal communication, 1998). Away from regions of observed current time series, model tides determined by Le Provost et al. [1998] (FES95.2 - Model) were used. Generally, corrections due to the tides were small for the shipboard ADCP/LADCP transports used in the following. Since the currents are variable at seasonal and shorter timescales, current cores in this region are not typically associated with water mass cores that would usually allow for an interpretation of longer-term mean circulations. Instead, water mass distributions on isopycnals are marked by high variability due to isolated lenses, making contouring difficult.

\section{Winter Monsoon Currents and Transports From Moored Array 1995-1996}

Time series of the 40-hour low-passed current vectors at station K12 are shown in Figure 4 to demonstrate the monsoonal cycle in the northern Somali Current regime. The strongest signals are associated with the Great Whirl (GW) developments during the summer monsoons of 1995 and 1996, where the GW was found to be much more northerly and stronger developed in the first than in the second year [Schott et al., 1997]. For the winter monsoon 1995-1996, the interesting result is that there is a net northeastward flow in the top $200 \mathrm{~m}$ at this station south of Socotra, but that below $200 \mathrm{~m}$, there is a southwestward undercurrent along the slope of Socotra (Figure 1). This undercurrent should be the source of the coastal southward undercurrent identified earlier off Somalia from hydrographic pressure gradients by Quadfasel and Schott [1983].

Time series of the two moorings, $\mathrm{K} 10$ and $\mathrm{K} 11$, in the Socotra Passage show that there is a continuous northward near-surface outflow into the Gulf of Aden, which does not have a clear monsoonal modulation (Figure 5).

At the $700 \mathrm{~m}$ level, there is still dominantly outflow on the eastern side, but on the western side we observe southward inflow into the Somali Basin most of the time. This inflow is particularly strong during the winter monsoon phase. This deep passage is the main inflow route of the Red Sea Water (RSW) into the western Indian Ocean, as will also become apparent from the ship section observations taken in January 1998.

Vector maps for the monsoon season current means, November 1, 1995, to Feburary 15, 1996, are shown in Figure 6 for different depth levels and are summarized with their standard deviations in Tables 1 and 2.

While the mean near-surface flow during the winter monsoon is eastward just south of Socotra (station $\mathrm{K} 12$ ), it is westward for all other stations between $7^{\circ}$ and $11^{\circ} \mathrm{N}$ south of Socotra down to the $200 \mathrm{~m}$ level and it is northward through the Socotra Passage (stations K10 and K11). This suggests that the near-surface westward inflow bifurcates near the coast into a northward branch off Somalia which then supplies the northward 


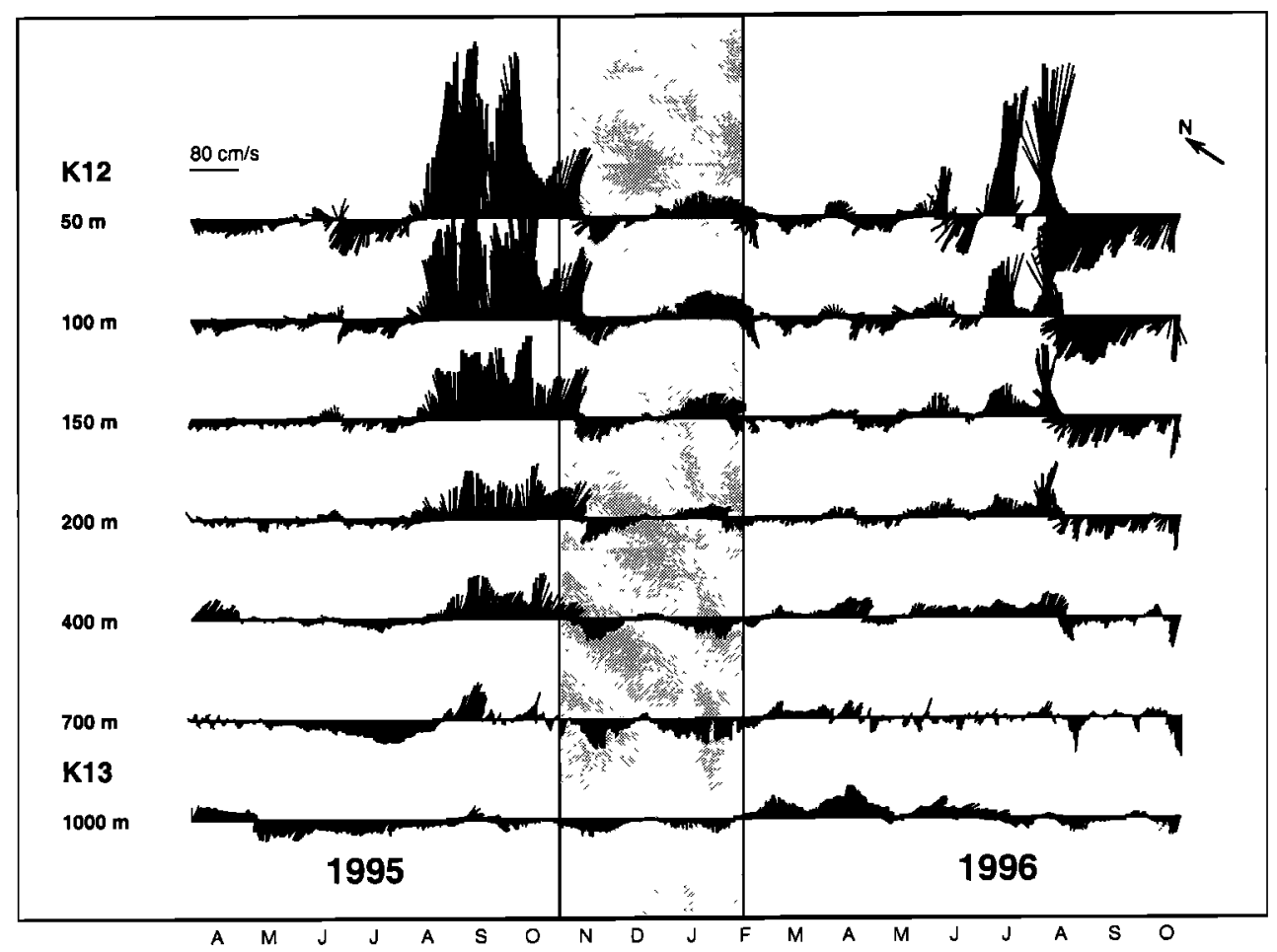

Figure 4. Vector time series of the 40-hour low-passed currents at the northern boundary station, K12, during April 1995 to October 1996. Currents are rotated for better visualization; see direction arrow at upper right.

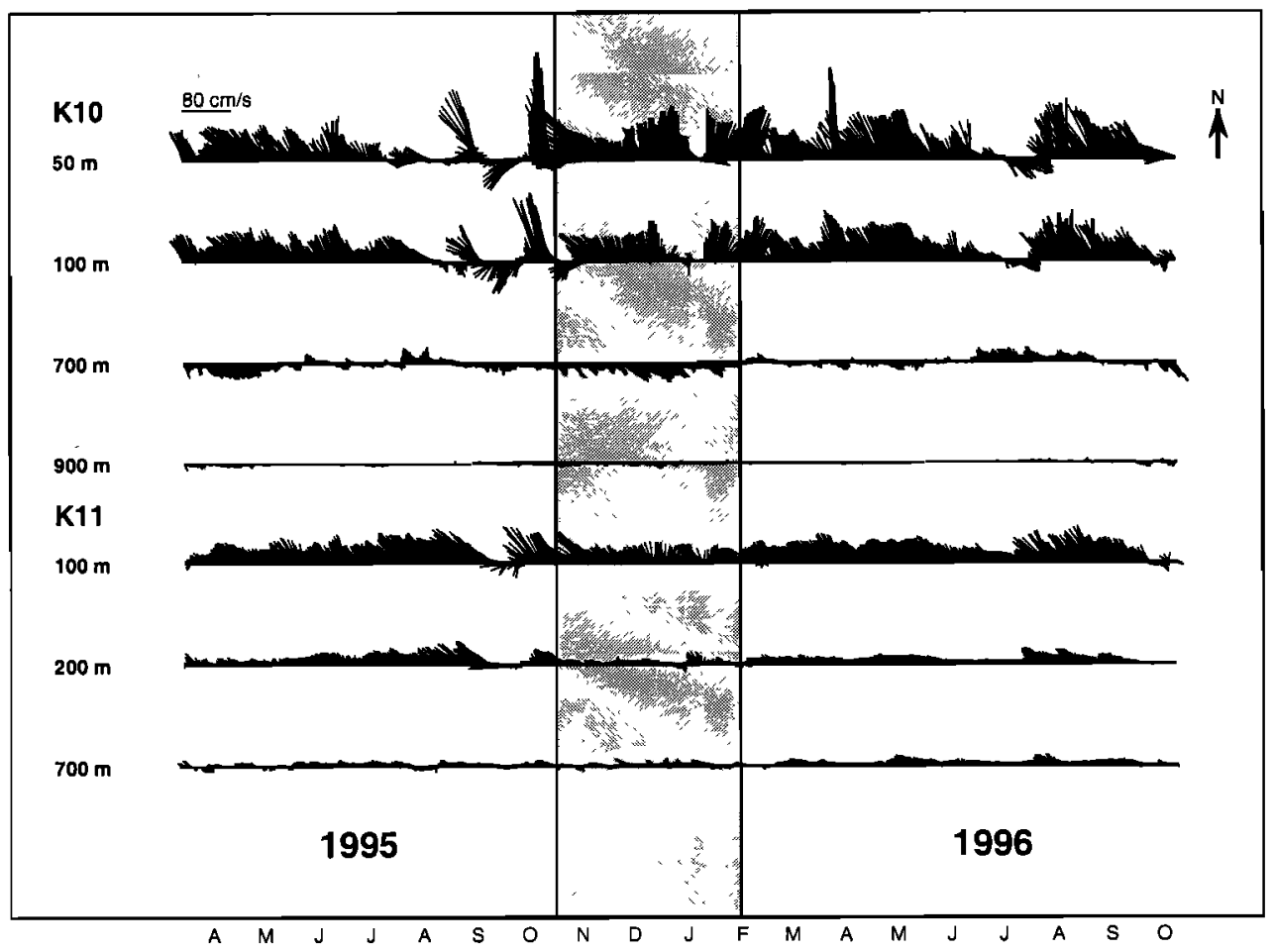

Figure 5. Vector time series of the 40-hour low-passed currents for several depths at stations $\mathrm{K} 10$ and $\mathrm{K} 11$ in the Socotra Passage; northward is up. 

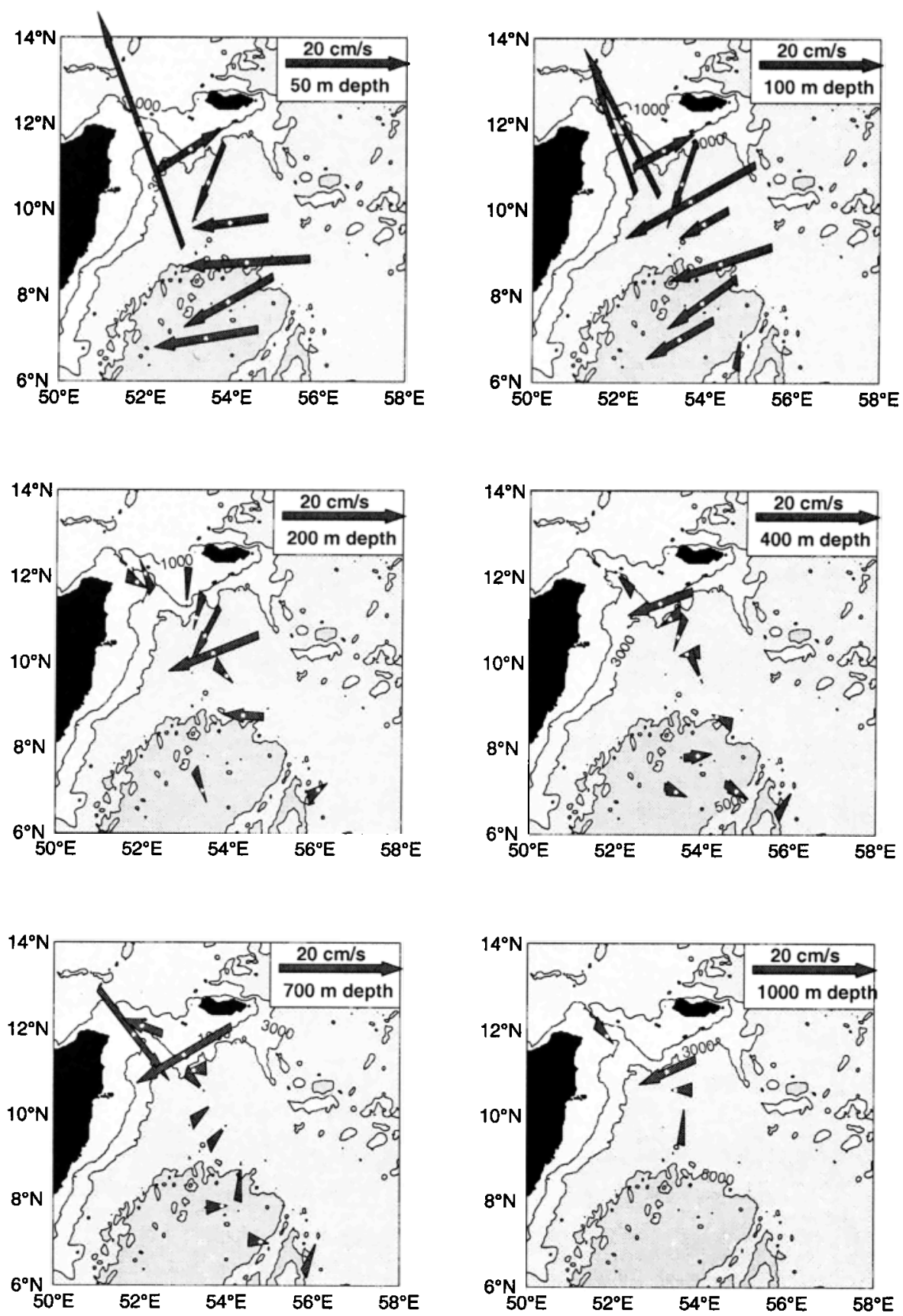

Figure 6. Current vector means from the moored array for the winter monsoon period, November 1, 1995, to February 15, 1996, for different depth levels.

upper layer throughflow through the Socotra Passage and the eastward boundary current south of Socotra.

At the $400-1000 \mathrm{~m}$ level the boundary current directly south of Socotra is southwestward, with monsoon season means of $18 \mathrm{~cm} \mathrm{~s}^{-1}$ at the $700 \mathrm{~m}$ level of station $\mathrm{K} 12$ and $8 \mathrm{~cm} \mathrm{~s}^{-1}$ at $1000 \mathrm{~m}$ at $\mathrm{K} 13$, farther offshore (Figure 4 and Table 2). The passage flow at the 700$900 \mathrm{~m}$ level is southward along the western slope, while currents farther offshore than K13 are weak. As mentioned above, these two undercurrents should combine to supply the southward coastal undercurrent off northern Somalia found by Quadfasel and Schott [1983].
The currents from mooring observations normal to the array (K12-K19) are shown both for an annual mean (Figure 7a) and for the winter monsoon season (Figure $7 \mathrm{~b}$ ). The annual mean (Figure $7 \mathrm{a}$ ) is dominated by the large summer monsoon currents and shows the structure of the Great Whirl with eastward flow north of $9^{\circ} \mathrm{N}$ (stations K12-K16) and westward recirculation to the south (K16-K19). The winter monsoon mean (Figure 7b) shows the small eastward core just south of Socotra with an estimated transport of only $0.8 \mathrm{~Sv}$ and the deep-reaching westward undercurrent underneath, carrying $\sim 6 \mathrm{~Sv}$. The mean westward flow in the sur- 
Table 1. Mean Velocities and Standard Deviation for the Annual Mean and for the Northeast Monsoon period in the Socotra Passage.

\begin{tabular}{|c|c|c|c|c|c|c|c|c|c|}
\hline \multirow[b]{2}{*}{ Type } & \multirow[b]{2}{*}{ Depth, m } & \multicolumn{4}{|c|}{ Nov. 1 to Feb. 15 , cgs } & \multicolumn{4}{|c|}{ April 1995 to April 1996, cgs } \\
\hline & & $\bar{u}$ & $\sigma_{u}$ & $\bar{v}$ & $\sigma_{v}$ & $\bar{u}$ & $\sigma_{u}$ & $\bar{v}$ & $\sigma_{v}$ \\
\hline \multicolumn{10}{|c|}{ Mooring K10 $11^{0} 51^{\prime} \mathrm{N}, 51^{0} 51^{\prime} \mathrm{E}$} \\
\hline $\mathrm{ADCP}$ & 50 & -14.23 & 32.04 & 38.26 & 23.48 & -17.83 & 25.56 & 33.69 & 28.49 \\
\hline $\mathrm{ADCP}$ & 100 & -738 & 21.11 & 20.22 & 23.14 & -16.70 & 18.40 & 24.18 & 23.46 \\
\hline $\mathrm{ADCP}$ & 200 & 3.07 & 12.49 & -2.07 & 15.47 & -6.38 & 12.50 & 921 & 18.33 \\
\hline $\mathrm{RCM}$ & 725 & 11.69 & 8.78 & -15.05 & 6.09 & 4.55 & 9.99 & -6.60 & 9.81 \\
\hline $\mathrm{RCM}$ & 900 & 2.05 & 3.55 & -2.42 & 2.26 & 1.69 & 2.93 & -1.32 & 1.94 \\
\hline \multicolumn{10}{|c|}{ Mooring K11 $12^{\circ} 03^{\prime} \mathrm{N}, 52^{\circ} 04^{\prime} \mathrm{E}$} \\
\hline $\mathrm{RCM}$ & 104 & -12.36 & 23.95 & 23.99 & 9.27 & -23.34 & 21.21 & 26.00 & 11.78 \\
\hline $\mathrm{RCM}$ & 206 & -1.92 & 10.85 & 4.77 & 5.19 & -10.65 & 13.64 & 9.65 & 7.58 \\
\hline $\mathrm{RCM}$ & 400 & -1.04 & 5.07 & 1.27 & 2.53 & -2.59 & 5.10 & 1.81 & 2.59 \\
\hline $\mathrm{RCM}$ & 725 & -6.61 & 8.19 & 2.44 & 4.10 & -6.20 & 6.98 & 2.83 & 3.85 \\
\hline
\end{tabular}

face layer between $7^{\circ}$ and $11^{\circ} \mathrm{N}$ amounts to $11.4 \mathrm{~Sv}$ on the basis of the mooring data points. The time series show, however, that this mean circulation (Figure 7) is superimposed by vigorous variability (Figure 4) with the standard deviations larger than the means (Table 2) such that shorter-period means will show quite different spatial patterns.

First estimates of time series for Socotra Passage transports derived from K10 and K11 data were presented by Schott et al. [1997] and showed variations from 0-5 Sv during the 1995-1996 winter monsoon. Reanalysis of the data including extrapolation toward the topography yielded even larger variations ranging from $3 \mathrm{~Sv}$ southward to $7 \mathrm{~Sv}$ northward during the winter monsoon period. The winter monsoon mean (averaged over the period November 1, 1995, to February 15, 1996) yielded a top to bottom transport of $2.2 \mathrm{~Sv}$ northward, which was dominated by the near-surface (upper $200 \mathrm{~m}$ ) flow amounting to $3.8 \mathrm{~Sv}$. Below the surface layer, there is net southward transport of $1.5 \mathrm{~Sv}$ covering both the Persian Gulf Water (PGW) layer (200-500 m) and the RSW layer below $500 \mathrm{~m}$, with most of the flow concentrated on the western part of the passage; the flow at the eastern side of the passage was comparatively weak. The southward flow of RSW varied from 0.2 to $0.8 \mathrm{~Sv}$ throughout the winter monsoon season at a mean transport of $0.5 \mathrm{~Sv}$ southward.

\section{Circulation During the Ship Survey of January 1998}

\subsection{Larger-Scale Connections}

Vector plots from the shipboard ADCP are shown in Figure 8 for the near-surface $(20-50 \mathrm{~m}$ ) (Figure 8a) and for the $150-300 \mathrm{~m}$ layer (Figure $8 \mathrm{~b}$ ). The surface flow shows westward inflow into the Somali Current in the $9^{\circ}-11^{\circ} \mathrm{N}$ latitude band that bifurcates southward and northward. The northern branch of Figure $7 \mathrm{a}$ par- tially supplies a throughflow through the Socotra Passage and partially circulates northeastward along the southeastern slope of Socotra. This part of the pattern is in agreement with the upper layer winter monsoon mean circulation found in the moored array currents (Figure 6). Part of the flow that turns southward in the ship survey recirculates across the $8^{\circ} \mathrm{N}$ line between $54^{\circ}$ and $56^{\circ} \mathrm{E}$. This structure is different from the winter monsoon mean flow, obtained from the moored station data (Figures 6 and 7), where westward upper-layer inflow occurred in the whole latitudinal band from $7^{\circ} \mathrm{N}$ to $11^{\circ} \mathrm{N}$. Given the large observed current variability in the period range of a few weeks, these differences are not surprising.

East and north of Socotra, intense mesoscale eddies are found, and it is not clear how the eastward outflow from the Somali Current that is attached to the coast in section B south of Socotra continues its way past this eddy field. At the deeper level the westward zonal inflow is still present at $9^{\circ}-11^{\circ} \mathrm{N}$ along $54^{\circ} \mathrm{E}$ (Figure $8 \mathrm{~b}$ ). At this level we have inflow through the Socotra Passage, while the circulation features observed in the northeastern part of the survey for the near-surface currents generally continue down to this level.

Along the northern boundary, off Oman, no consistent boundary current is found in the two sections normal to the coast, apparently because of strong eddy activity. While at the $59^{\circ} \mathrm{E}$ section, coastal currents off Arabia are eastward, the flow near the coast at $57^{\circ} \mathrm{E}$ is westward (Figure 8).

Salinity sections for the upper $800 \mathrm{~m}$ are shown in Plate 1 for four sections (marked A-D in Figure 1). The subduction of Arabian Sea surface water can be seen in the sections; maximum surface-mixed layer salinity occurs in the sections C and D northeast of Socotra, and the southward subsurface penetration of this maximum is seen in section B, south of Socotra.

At the RSW level, around the density level $\sigma_{\Theta}=$ 27.2 [e.g., Quadfasel, 1982], maximum salinities are 
Table 2. Mean Velocities and Standard Deviation for the Annual Mean and for the Northeast Monsoon period South of Socotra.

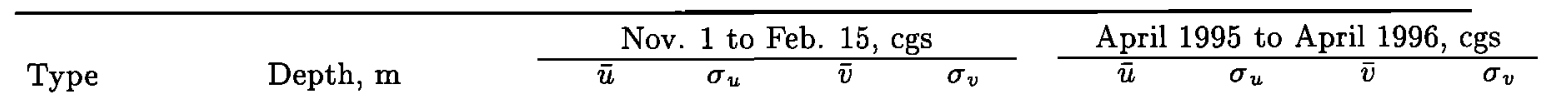

\begin{tabular}{|c|c|c|c|c|c|c|c|c|c|}
\hline \multicolumn{10}{|c|}{ Mooring K12 $11^{\circ} 24^{\prime} \mathrm{N}, 53^{\circ} 00^{\prime} \mathrm{E}$} \\
\hline ADCP & 50 & 10.57 & 32.87 & 7.00 & 18.3 & 22.55 & 63.37 & 18.64 & 33.41 \\
\hline ADCP & 100 & 9.91 & 32.23 & 5.48 & 15.14 & 15.16 & 45.93 & 16.08 & 25.33 \\
\hline ADCP & 200 & -0.02 & 19.79 & -1.62 & 6.20 & 5.27 & 21.18 & 4.88 & 10.19 \\
\hline RCM & 400 & -10.41 & 12.30 & -3.93 & 6.31 & 3.02 & 19.55 & 1.33 & 7.54 \\
\hline $\mathrm{RCM}$ & 700 & -15.33 & 10.53 & -9.28 & 6.03 & -5.37 & 16.59 & -4.33 & 5.80 \\
\hline \multicolumn{10}{|c|}{ Mooring K13 $11^{0} 00^{\prime} \mathrm{N}, 53^{0} 13^{\prime} \mathrm{E}$} \\
\hline $\mathrm{RCM}$ & 150 & 3.90 & 25.73 & -5.06 & 21.18 & 11.55 & 30.68 & 8.32 & 20.07 \\
\hline $\mathrm{RCM}$ & 200 & -0.92 & 15.81 & -3.83 & 13.20 & 5.77 & 16.61 & 4.51 & 11.54 \\
\hline $\mathrm{RCM}$ & 400 & -2.95 & 6.60 & -2.25 & 3.66 & 1.51 & 6.59 & 0.89 & 4.63 \\
\hline $\mathrm{RCM}$ & 700 & -2.63 & 4.25 & -0.45 & 1.85 & 0.15 & 5.47 & 0.43 & 3.21 \\
\hline $\mathrm{RCM}$ & 1000 & -9.14 & 6.38 & -4.21 & 3.68 & -3.91 & 14.88 & -1.77 & 7.75 \\
\hline $\mathrm{RCM}$ & 2000 & -0.23 & 7.61 & 1.19 & -0.60 & -0.19 & 10.30 & 0.35 & 4.30 \\
\hline $\mathrm{RCM}$ & 3000 & -1.78 & 3.27 & -0.60 & 3.25 & -1.06 & 2.55 & -0.40 & 2.29 \\
\hline \multicolumn{10}{|c|}{ Mooring $K 1410^{0} 36^{\prime} N, 53^{\circ} 25^{\prime} E$} \\
\hline $\mathrm{ADCP}$ & 50 & -5.11 & 34.63 & -12.97 & 31.36 & 31.67 & 71.25 & 10.04 & 33.35 \\
\hline $\mathrm{ADCP}$ & 100 & -4.75 & 35.22 & -14.34 & 30.25 & 18.52 & 48.38 & 8.72 & 31.77 \\
\hline $\mathrm{ADCP}$ & 200 & -4.77 & 19.28 & -9.35 & 17.69 & 5.83 & 20.23 & 5.70 & 18.57 \\
\hline ADCP & 400 & -1.37 & 11.30 & -4.42 & 11.93 & 3.74 & 11.74 & 2.24 & 12.12 \\
\hline $\mathrm{RCM}$ & 700 & 0.82 & 9.36 & -0.91 & 9.06 & 4.51 & 11.39 & 3.19 & 12.90 \\
\hline $\mathrm{RCM}$ & 1000 & -1.36 & 7.49 & -0.04 & 4.26 & 3.69 & 10.26 & 2.78 & 10.75 \\
\hline \multirow{2}{*}{\multicolumn{10}{|c|}{ Mooring K15 $10^{\circ} 12^{\prime} N, 53^{\circ} 38^{\prime} E$}} \\
\hline & & & & & & & & & \\
\hline $\mathrm{RCM}$ & 100 & -20.87 & 24.60 & -12.03 & 34.34 & 7.96 & 39.80 & -4.27 & 25.95 \\
\hline $\mathrm{RCM}$ & 200 & -14.51 & 16.49 & -6.01 & 18.70 & 0.54 & 20.05 & 0.83 & 16.51 \\
\hline $\mathrm{RCM}$ & 400 & -2.40 & 9.36 & -0.59 & 12.60 & 0.08 & 10.05 & 1.14 & 12.21 \\
\hline $\mathrm{RCM}$ & 1000 & 0.09 & 3.97 & 0.64 & 5.62 & 1.95 & 4.44 & 0.77 & 5.26 \\
\hline $\mathrm{RCM}$ & 2000 & 0.09 & 2.45 & -3.02 & 2.63 & 0.48 & 2.47 & -0.15 & 3.43 \\
\hline $\mathrm{RCM}$ & 3500 & -1.83 & 5.75 & -2.80 & 4.35 & -1.56 & 4.04 & -0.11 & 4.69 \\
\hline \multicolumn{10}{|c|}{ Mooring $K 169^{0} 40^{\prime} N, 53^{0} 56^{\prime} E$} \\
\hline $\mathrm{ADCP}$ & 50 & -12.24 & 37.04 & -1.76 & 52.49 & 5.18 & 37.00 & -5.01 & 40.35 \\
\hline $\mathrm{ADCP}$ & 100 & -8.03 & 30.87 & -4.71 & 46.66 & 5.22 & 30.91 & -4.82 & 34.13 \\
\hline $\mathrm{ADCP}$ & 200 & 1.99 & 15.83 & -2.34 & 25.02 & 4.98 & 16.32 & -2.70 & 18.30 \\
\hline ADCP & 400 & 0.77 & 5.12 & -1.90 & 8.06 & 0.68 & 5.32 & 0.89 & 7.33 \\
\hline $\mathrm{RCM}$ & 700 & 0.86 & 3.13 & 1.05 & 7.36 & 0.48 & 4.29 & -1.62 & 6.21 \\
\hline RCM & 2000 & 4.74 & 3.92 & 0.02 & 5.42 & 2.04 & 5.05 & -0.56 & 5.24 \\
\hline $\mathrm{RCM}$ & 4000 & 1.82 & 2.62 & 1.21 & 2.28 & 0.23 & 2.16 & 0.46 & 1.60 \\
\hline RCM & 4500 & 2.25 & 7.26 & 3.37 & 6.08 & -0.03 & 5.33 & 0.88 & 4.25 \\
\hline \multicolumn{10}{|c|}{ Mooring $K 178^{\circ} 45^{\prime} N, 7^{0} 50^{\prime} E$} \\
\hline $\mathrm{ADCP}$ & 50 & -20.42 & 19.25 & -1.33 & 36.79 & -16.23 & 43.46 & -27.92 & 49.77 \\
\hline ADCP & 100 & -16.56 & 15.96 & -5.90 & 0.25 & -20.36 & 39.74 & -24.96 & 43.33 \\
\hline ADCP & 200 & -6.54 & 5.90 & 0.25 & 19.71 & -12.88 & 19.18 & -8.92 & 24.00 \\
\hline $\mathrm{RCM}$ & 400 & -1.51 & 2.58 & 0.76 & 8.68 & -3.41 & 4.46 & -0.77 & 6.45 \\
\hline $\mathrm{RCM}$ & 700 & 0.15 & 2.97 & 1.89 & 7.73 & -1.85 & 3.74 & -0.72 & 6.25 \\
\hline \multirow{2}{*}{\multicolumn{10}{|c|}{ Mooring $K 187^{0} 50^{\prime} N, 53^{0} 54^{\prime} E$}} \\
\hline & & & & & & & & & \\
\hline $\mathrm{ADCP}$ & 50 & -14.47 & 25.26 & -8.28 & 13.94 & -25.07 & 47.59 & -24.53 & 41.41 \\
\hline ADCP & 100 & -11.19 & 21.14 & -8.36 & 13.42 & -27.45 & 42.27 & -17.11 & 31.90 \\
\hline ADCP & 400 & 4.44 & 13.22 & 0.62 & 16.04 & -4.92 & 13.56 & -1.40 & 13.39 \\
\hline $\mathrm{RCM}$ & 700 & 1.59 & 4.03 & 0.11 & 6.58 & -1.49 & 4.45 & -0.74 & 5.34 \\
\hline $\mathrm{RCM}$ & 2000 & 0.42 & 1.78 & 0.66 & 2.70 & -0.09 & 2.12 & 0.59 & 2.66 \\
\hline \multicolumn{10}{|c|}{ Mooring K19 $07^{\circ} 00^{\prime} N, 53^{0} 25^{\prime} E$} \\
\hline $\mathrm{ADCP}$ & 50 & -16.95 & 17.99 & -2.99 & 13.53 & -28.88 & 41.81 & -6.61 & 47.01 \\
\hline $\mathrm{ADCP}$ & 100 & -10.97 & 12.75 & -6.38 & 9.01 & -27.22 & 38.33 & -3.68 & 37.32 \\
\hline ADCP & 200 & 1.38 & 6.27 & -3.85 & 14.05 & -6.72 & 13.62 & -1.74 & 20.22 \\
\hline ADCP & 400 & 3.62 & 5.36 & -1.56 & 16.10 & -0.58 & 9.96 & -1.08 & 16.79 \\
\hline
\end{tabular}



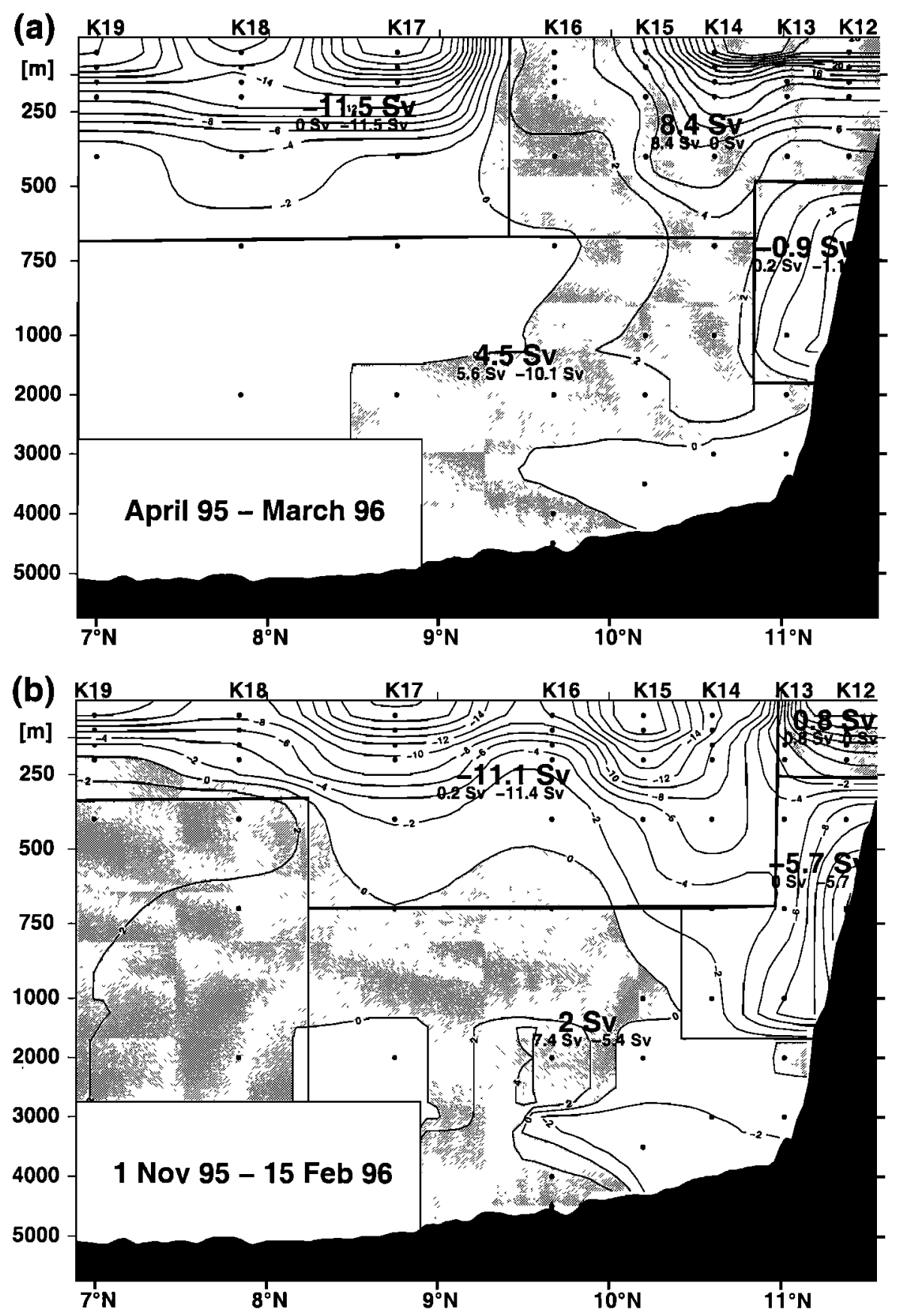

Figure 7. Currents and transports normal to the mooring line (moorings K12-K19) south of Socotra: (a) annual mean (April 1995 to March 1996) and (b) winter monsoon (November 1995 to February 1996). Transport numbers (in Sverdrups) for boxes are marked. Heavy numbers in boxes are net transports for the boxes; numbers below them are eastward (left) and westward (right) contributions to box transports. Eastward currents are shaded; the contour interval 2 $\mathrm{cm} \mathrm{s}^{-1}$. The vertical coordinate is stretched for the upper $1000 \mathrm{~m}$.

found along section A, running from Abd al Kuri to the African continental slope. The salinity maximum is concentrated on the western slope, indicating the inflow of RSW into the Indian Ocean through the Socotra Passage. High salinities at $\sigma_{\Theta}=27.2$ are also observed along the northern border at $57^{\circ} \mathrm{E}$ (section $\mathrm{D}$ ) but not south of Socotra (section B). The RSW, besides its high salinity, is also distinguishable by its higher $\mathrm{O}_{2}$ values $\left(>0.3 \mathrm{~mL} \mathrm{~L}^{-1}\right)$ from the background water $(<0.2 \mathrm{~mL}$ $\mathrm{L}^{-1}$ ) of the northern Arabian Sea. Along the $59^{\circ} \mathrm{E}$ section (Figure 1), the near-coastal salinities and oxygens are both low, suggesting that the secondary maximum in section $\mathrm{D}$ is an isolated lense rather than a coherent RSW penetration along the northern border. 

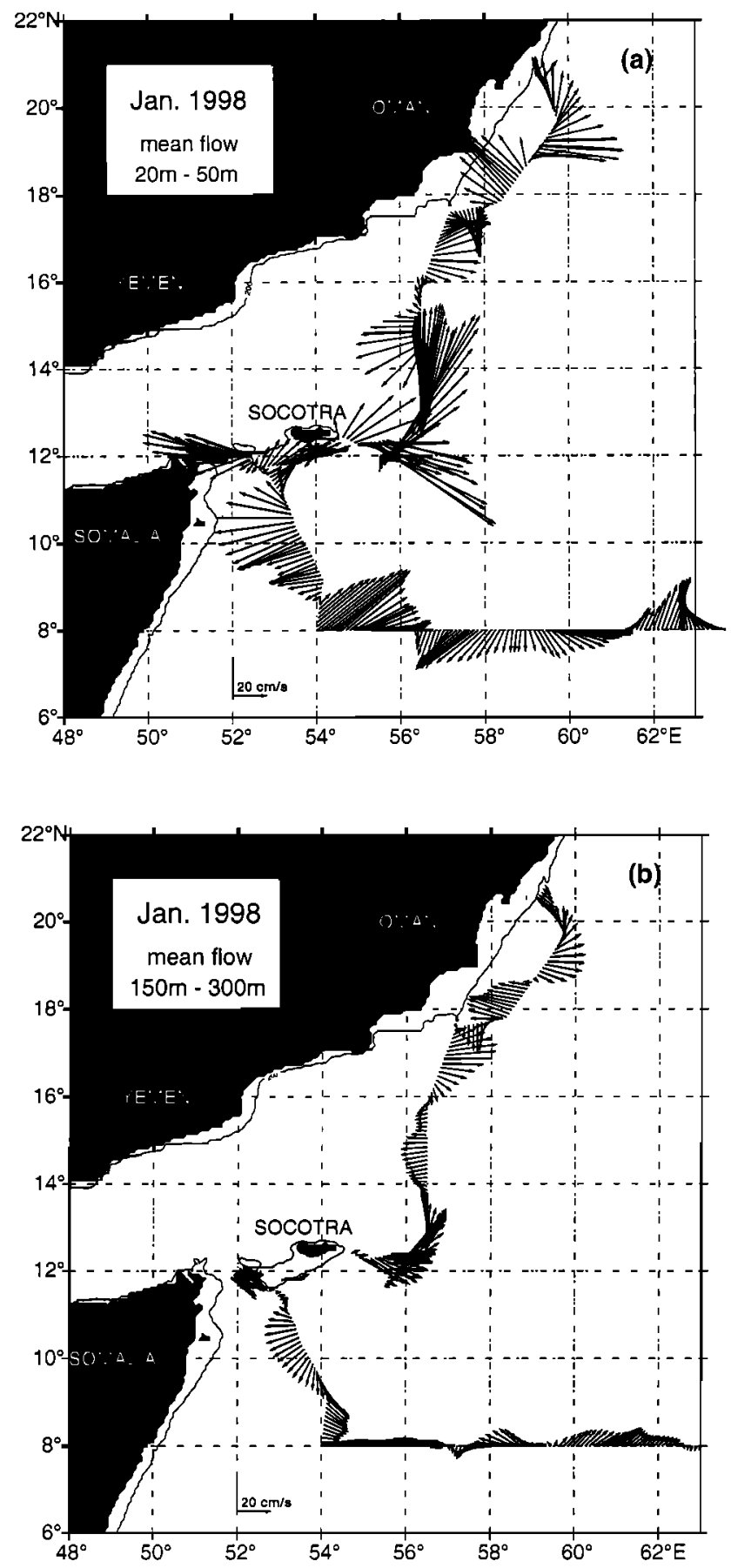

Figure 8. Shipboard ADCP currents during January 14-27, 1998, for two depth ranges: (a) $20-50 \mathrm{~m}$ and (b) $150-300 \mathrm{~m}$.

At $\sigma_{\ominus}=26.6$, corresponding to the density level of the Persian Gulf outflow at $250-300 \mathrm{~m}$ depth, the maximum values combined with low $\left(<0.1 \mathrm{~mL} \mathrm{~L}^{-1}\right) \mathrm{O}_{2}$ values are found in the $60^{\circ} \mathrm{E}$ section; higher values are found east of Socotra than along the northern border. The distributions at both levels $\sigma_{\Theta}=27.2$ and 26.6 show how strongly the northern Arabian Sea is dominated by mesoscale water mass features.

\subsection{Passage Currents}

The shipboard ADCP and LADCP currents that were determined from the six stations across that passage, are shown in Figure 9. They are corrected with the tidal constituents determined from moorings K10 and K11, but using the Le Provost et al. [1998] tidal model yields rather similar results. The near-surface outflow regime during the ship survey is shallow, only $\sim 100 \mathrm{~m}$ thick, and yields a northward outflow transport of $2.2 \mathrm{~Sv}$ above $\sigma_{\Theta}=25.4$ compared to $3.8 \mathrm{~Sv}$ for the near-surface layer as the winter monsoon mean estimate from the current meter records. Below it, there is southward inflow, but it is restricted to the western side of the passage, and its deep current core of more than $30 \mathrm{~cm} \mathrm{~s}^{-1}$ is associated with the RSW salinity maximum of Plate 1. The inflow transport into the Somali Basin below $\sigma_{\Theta}=25.4$ totals $5.4 \mathrm{~Sv}$, while the lower part on the eastern side shows a weak outflow of $1.0 \mathrm{~Sv}$.

This winter monsoon current structure is similar to that of summer 1993 reported by Fischer et al. [1996], where the inflow was also concentrated on the western channel side. The mooring data of Figure 5 also indicate this cross-channel structure to be representative of the year-round structure on which strong variability is superimposed. Compared to the net northward transport of $2.2 \mathrm{~Sv}$ from the moored stations for the winter monsoon 1995-1996 period mean, this net southward throughflow of 2.2 Sv through the Socotra Passage during the time of the ship section has to be explained in terms of the significant current variability observed in the moored currents (Figure 5). At depth, however, the large RSW current core of January 1998 (Figure 9) confirms that the 1995 winter monsoon maximum observed at the $700 \mathrm{~m}$ level of station $\mathrm{K} 10$ is not randomly occuring but rather suggests a winter monsoon RSW inflow maximum in agreement with the observations of Murray and Johns [1997] at the exit of the Red Sea.

\subsection{Ship Section Along the Mooring Line}

The shipboard ADCP currents along this section (B in Figure 1) were corrected for tides on the basis of our own current meter record from stations K12-K19 (M. Dengler, personal communication, 1998), and for comparison they were also corrected by using the tidal model constituents of Le Provost et al. [1998], and the corrections to the transports were found to be small, as is illustrated by the following example. The tidal aliasing of the shipboard measurements based on the Le Provost et al. [1998] model tides accumulates to an apparent westward inflow of $0.5 \mathrm{~Sv}$ across the $54^{\circ} \mathrm{E} \mathrm{sec}-$ tion (Figure 10) for the layer above $\sigma_{\ominus}=27.3$ (the RSW layer) and latitude range $8^{\circ}-12^{\circ} \mathrm{N}$; there is no net difference for that section between the estimation based on the moored records and those from the Le Provost et al. [1998] model, although the details differ. However, we tried to remove this effect by subtracting the estimate of the barotropic tides to reduce further this 

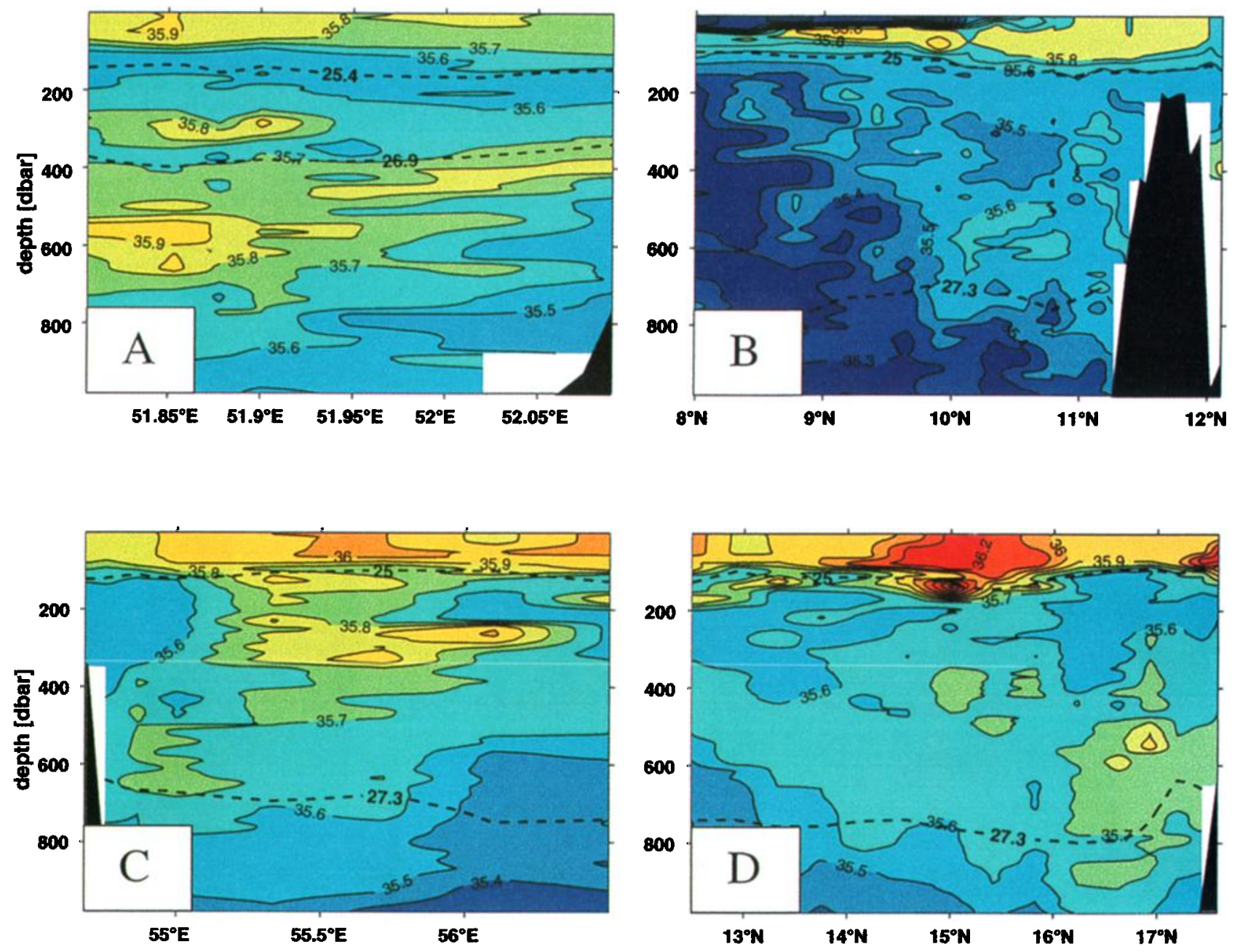

Plate 1. Salinity sections for upper $800 \mathrm{~m}$ : (a) Socotra Passage section (stations 49-57, section A), (b) $53^{\circ} \mathrm{E}$ section south of Socotra (stations $30-46$, section B), (c) $12^{\circ} \mathrm{N}$ section east of Socotra (stations 58-68, section $\mathrm{C}$ ), and (d) $57^{\circ} \mathrm{E}$ section south of Oman (stations. 68-82, section D). Also marked are isopycnals $\sigma_{\Theta}=25.4$ and 26.9 ; for section locations and station numbers, see Figure 1.

$10 \%$ effect. The merged shipboard and LADCP currents along the $54^{\circ} \mathrm{E}$ section (stations $30-46$, Figure 10) show the westward inflow into the boundary regime in the $8.5^{\circ}-10.5^{\circ} \mathrm{N}$ latitude range and the northeastward recirculation, which was already discussed in conjunction with Figure 7, where it was shown that this inflow and recirculation reaches down to $500 \mathrm{~m}$, but with its intensive part limited to the layer above $\sigma_{\Theta}=25.0$, in correspondense with the northward passage outflow, which was also limited to the upper $100 \mathrm{~m}$ (Figure 9).

Underneath the northeastward recirculation currents off Socotra we find deep-reaching westward flow toward Somalia that supposedly feeds into the southward coastal undercurrent off Somalia described earlier [Quadfasel and Schott, 1983]. Its current maximum is quite deep during the ship survey, at $1000-2000 \mathrm{~m}$. The westward inflow transport is $\sim 11 \mathrm{~Sv}$ in the upper
$700 \mathrm{~m}$, that of the northeastward return branch south off Socotra is $1.8 \mathrm{~Sv}$, and the transport of the westward undercurrent across the box marked in Figure 10 is $2.2 \mathrm{~Sv}$ between 500 and $2000 \mathrm{~m}$. The moorings also showed a monsoon season westward mean in this depth range (Figure $7 \mathrm{~b}$ ), which therefore appears to be a robust winter monsoon feature. Overall, comparing Figures 7 and 10 shows general agreement among the two flow structures north of $\sim 9^{\circ} \mathrm{N}$. South of $9^{\circ} \mathrm{N}$ as mentioned already earlier, the mean surface flow from the moored currents continues to be westward, while eastward recirculation is observed in the ship survey situation of January 1998. The relatively low salinity at the RSW core layer of the westward undercurrent in the $54^{\circ} \mathrm{E}$ section (B in Plate 1) suggests that the RSW insertion into the Somali Basin occurs along the Somali coast past the passage and not around Socotra. 


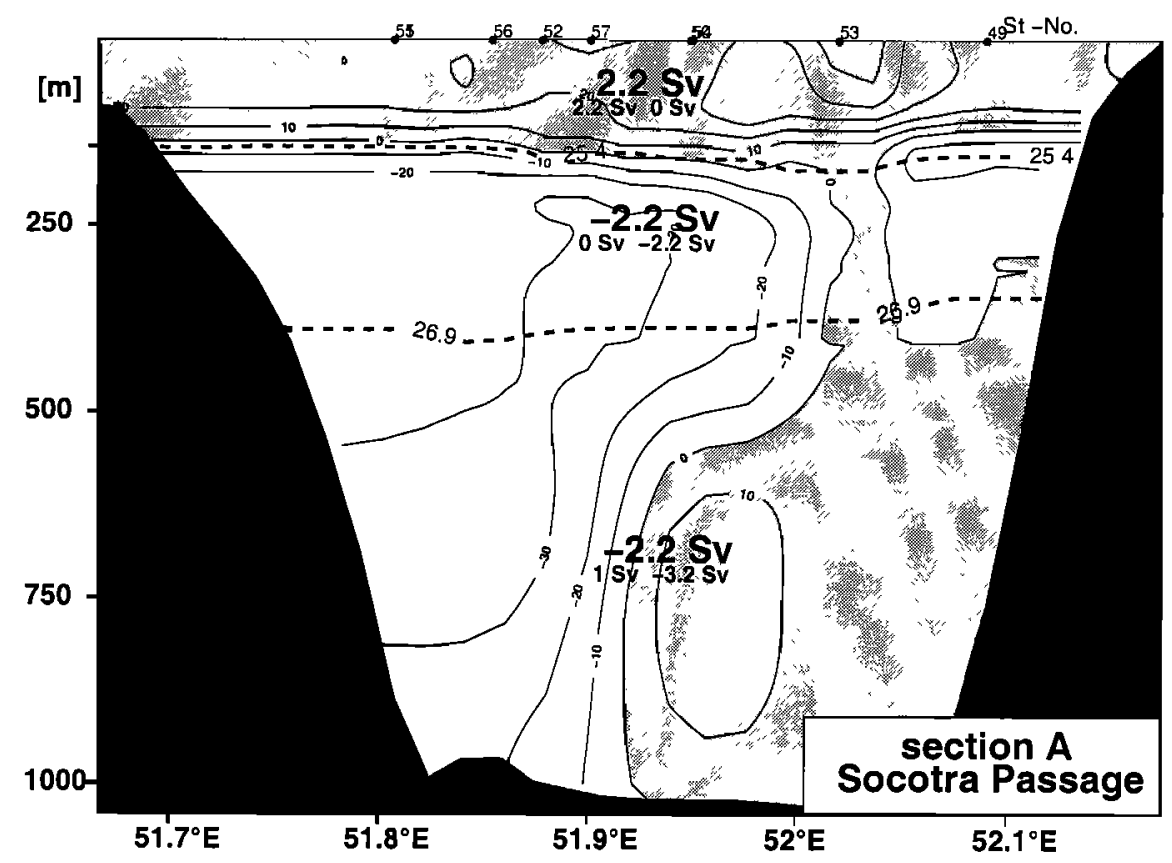

Figure 9. Currents and transports parallel to Socotra Passage axis (section A). Northward is positive (shaded); the contour interval is $20 \mathrm{~cm} \mathrm{~s}^{-1}$. Also marked are isopycnals $\sigma_{\Theta}=25.4$ and 26.9. Net transports for the three layers separated by the two isopycnals are given in Sverdrups (heavy numbers). Light numbers below are northward (left) and southward (right) box transport contributions.

\subsection{Flow Between Socotra and the Arabian Peninsula}

Currents and transports are shown in Figure 11 for the $12^{\circ} \mathrm{N}$ section and in Figure 12 for the $57^{\circ} \mathrm{E}$ section, both from merged shipboard and LADCP data and corrected with the Le Provost et al. [1998] tidal model constituents. Figure 11 shows the continuation of the shelf edge flow of $\sim 2 \mathrm{~Sv}$ off eastern Socotra, which crossed the $54^{\circ} \mathrm{E}$ section south of Socotra. Offshore, the reversing currents nearly compensate above $\sigma_{\ominus}=25.0$, where good resolution in the ADCP data exists, while the transport difference within the $\sigma_{\Theta}=25.0-27.3$ layer

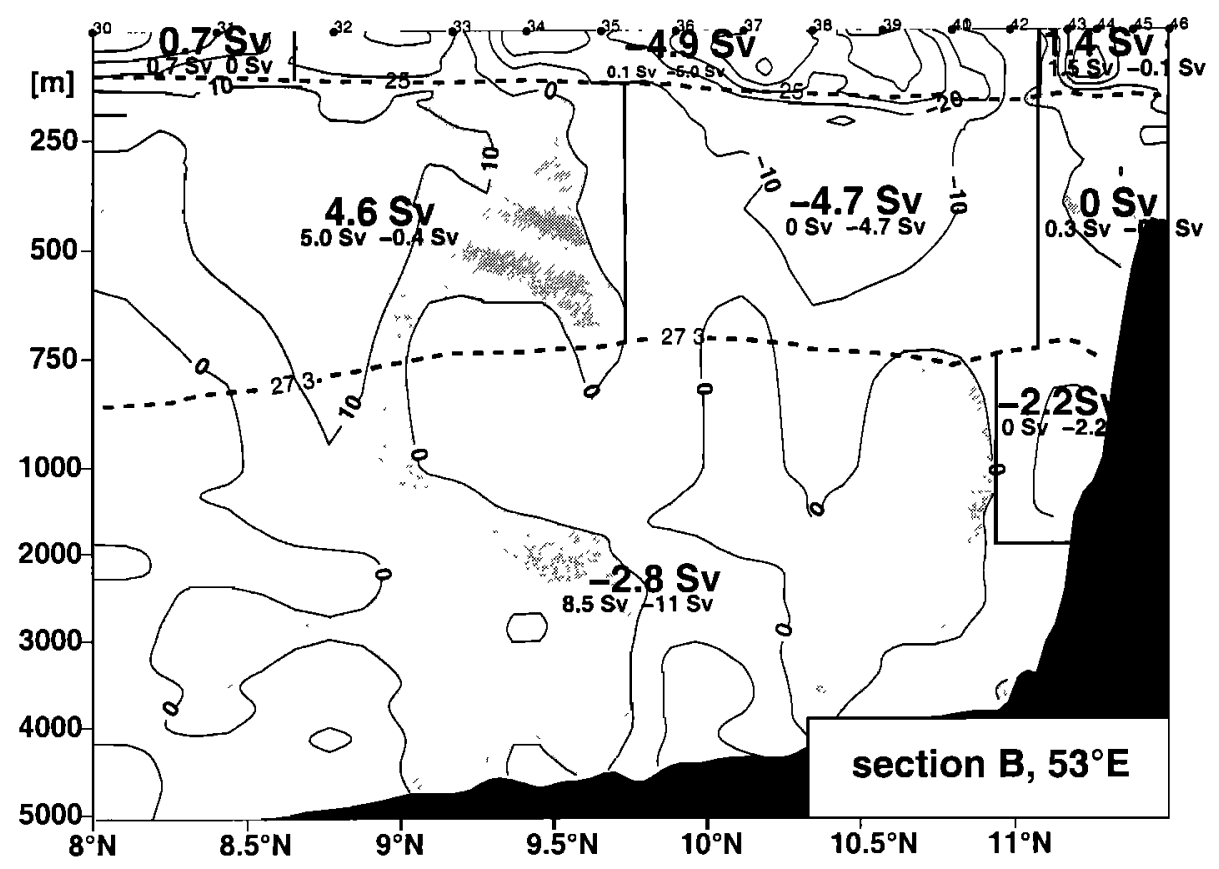

Figure 10. As for Figure 9, but for section $\mathrm{B}, \sim 53^{\circ} \mathrm{E}$, south of Socotra. Positive currents (shaded) and transports are eastward. The vertical coordinate is stretched for the upper $1000 \mathrm{~m}$. 


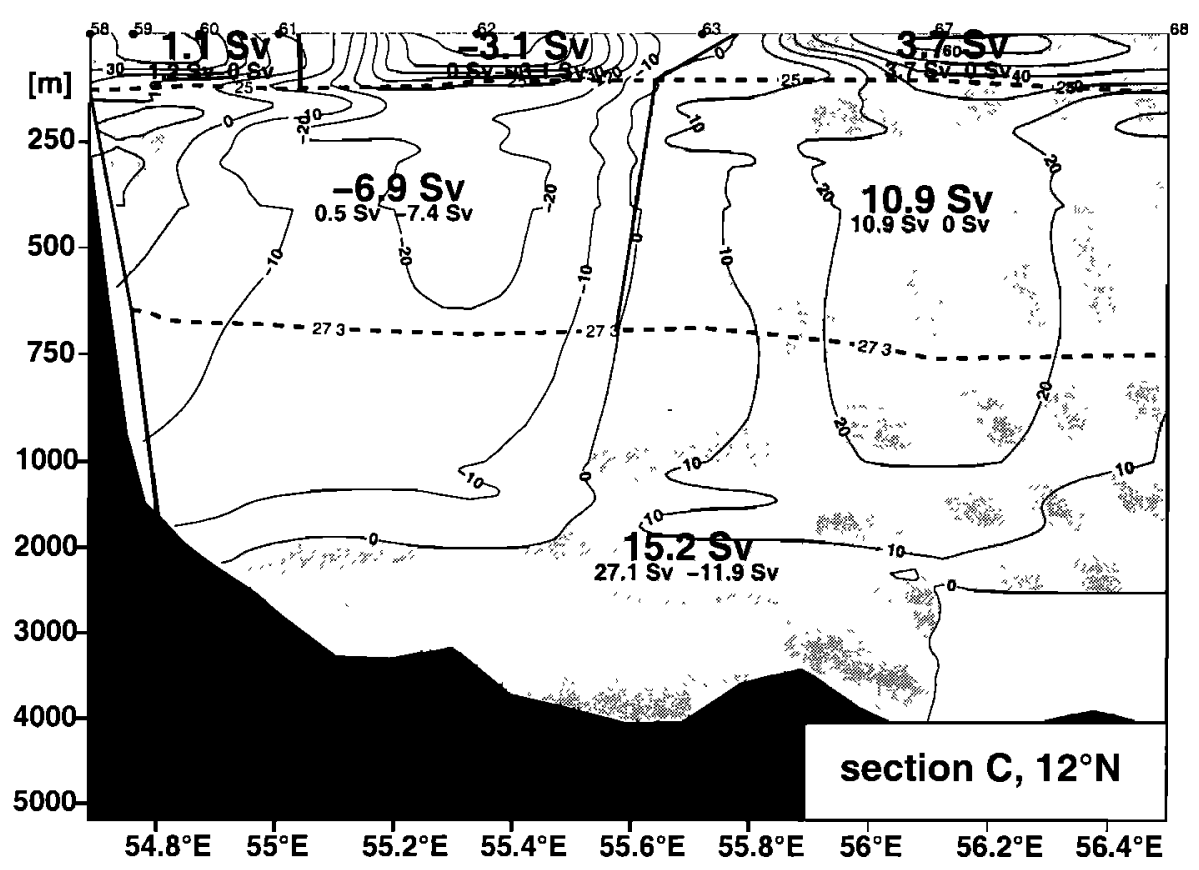

Figure 11. As for Figures 9 and 10 but for $12^{\circ} \mathrm{N}$ section (C) east of Socotra. Positive currents (shaded) and transports are northward.

between the northward and the southward transports may partially be due to the deep features not being resolved by the LADCP profiles. The salinities in Plate 1 confirm that this section is not a supply route of RSW into the Indian Ocean, at least not during the winter monsoon. Offshore, high salinities near $\sigma_{\Theta}=26.6$ along the $12^{\circ} \mathrm{N}$ section (Plate 1 ) indicate the presence of PGW of which remnants are still seen in the Socotra Passage.

Along the $57^{\circ} \mathrm{E}$ section (Figure 12) an eastward bound ary current off the south coast of Oman is observed with a transport of $11.6 \mathrm{~Sv}$ above $\sigma_{\Theta}=27.3$, of which $2.4 \mathrm{~Sv}$ are contributed by the surface-intensified flow above $\sigma_{\Theta}=25.0$. High salinities at the RSW level near the northern coast (Plate 1) indicate that occasional RSW spreading may occur in this direction, but it is interesting to note that no PGW core is detected at the $\sigma_{\Theta}=26.6$ level. In the $13^{\circ}-16^{\circ} \mathrm{N}$ band the flow is westward with $2.4 \mathrm{~Sv}$ above $\sigma_{\Theta}=25.0$ and a total of $10.5 \mathrm{~Sv}$ above $\sigma_{\Theta}=27.3$. The net eastward flow north of $13^{\circ} \mathrm{N}$ in the upper $700 \mathrm{~m}$ is near zero.

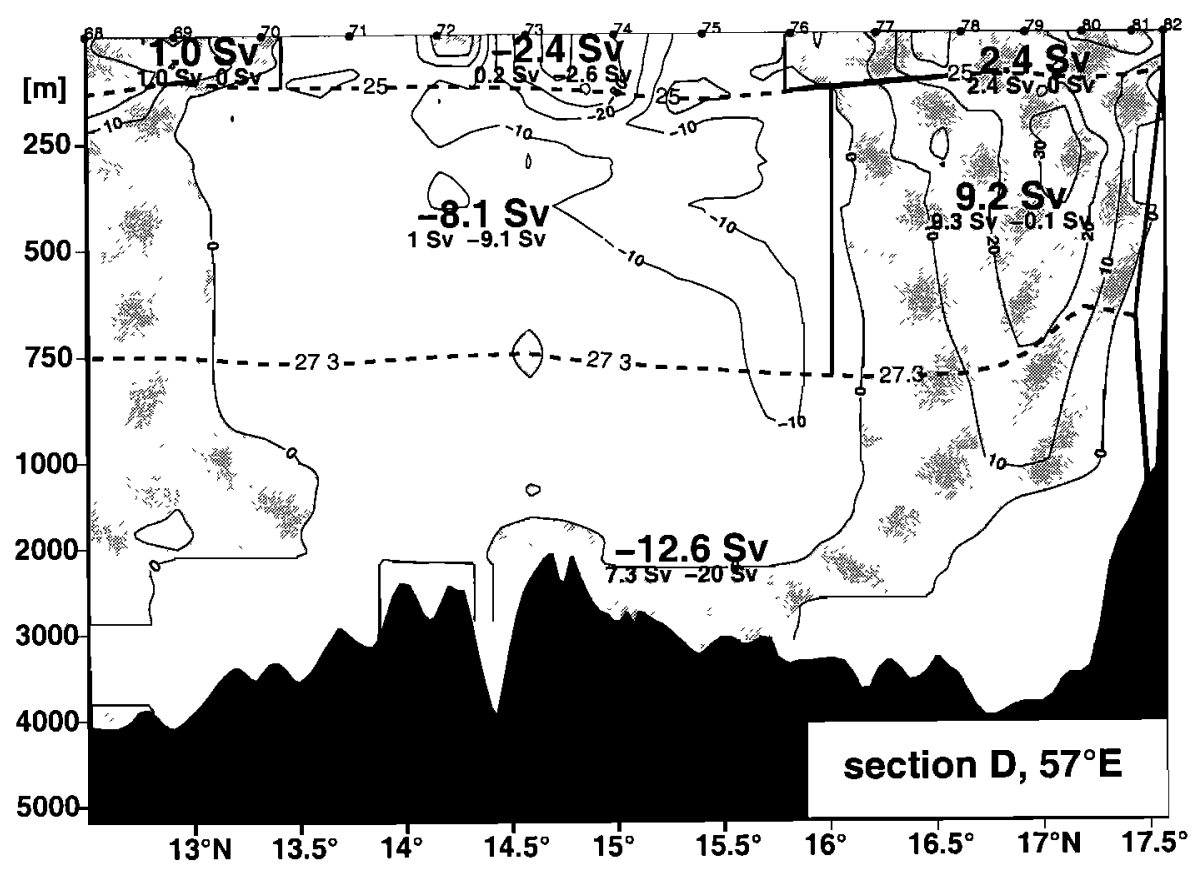

Figure 12. As for Figures 9 and 10 but for $57^{\circ} \mathrm{E}$ section (D) south of Oman. 

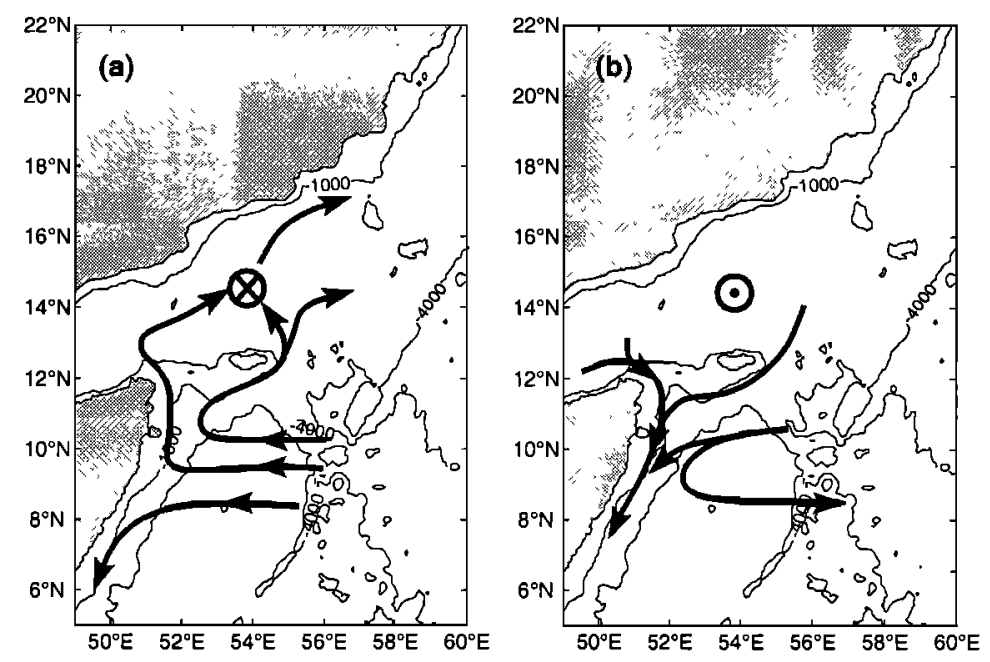

Figure 13. Schematic circulation of the northern Somali Current regime during winter monsoon. (a) upper layer $\left(\sigma_{\Theta}<25.0\right)$ with subduction out of the layer which is indicated by a circle with a cross in it, and (b) intermediate layer $\left(25.0<\sigma_{\Theta}<27.3\right)$ with subduction into the intermediate layer which is indicated by a circle with a dot in it.

\section{Discussion and Conclusions}

The winter monsoon circulation of the northwest Indian Ocean was observed with moored current meter stations during the winter of 1995-1996 and with a shipboard survey in January 1998. A complex situation of westward inflow, exchange through the Socotra Passage between the island of Abd al Kuri and the African continent, and northwestward recirculation emerged. Figure 13 summarizes schematically the flow patterns for the upper and intermediate layers on the basis of moored and shipboard observations. The westward inflow in the near surface layer in the latitude range $8.5^{\circ}-10.5^{\circ} \mathrm{N}$ passed partially northward through the Socotra Passage and recirculated partially eastward along the southern slope of Socotra. Part of this inflow also served to supply the southward coastal Somali Current, although no observations could be taken in the coastal region to quantify this fraction.

At the subsurface level, below $\sim 100 \mathrm{~m}$, a southward undercurrent inflow through the Socotra Passage was observed that was concentrated on the African slope and had its current maximum at the salinity maximum core of the RSW. The moored current observations in the passage suggest that maximum RSW inflow into the Indian Ocean through this passage occurs during the winter monsoon, in agreement with the winter maximum observed by Murray and Johns [1997] in the Red Sea outflow. Westward undercurrent flow was also observed below the eastward surface outflow just south of Socotra. This undercurrent did not carry high-salinity RSW properties, thus indicating that the main RSW inflow route into the Indian Ocean is the Socotra Passage.

\subsection{Upper Layer Transport Budget}

The water masses indicate subduction out of the upper layer into the thermocline layer for the region between Socotra and the Arabian Peninsula (Figure 13). Because of the large short-period variability obvious from the moored time series (Figure 13), it is, of course, unreasonable to expect a closed budget for the box enclosed by the combined sections A, C, and D (Figure 13), but we will check on it here anyway. For the layer above $\sigma_{\Theta}=25.0$ we obtain a northward throughflow of 2.2 Sv through the Socotra Passage into the box, a further small net inflow of $1.2 \mathrm{~Sv}$ through the $12^{\circ} \mathrm{N}$ section (C), and a small net outflow of $1.0 \mathrm{~Sv}$ through the $57^{\circ} \mathrm{E}$ section (D), i.e., a total of $2.4 \mathrm{~Sv}$ net inflow into the box. This number has to be compared with the sum of the absolute transports through the box boundaries for the top layer, which is $16.8 \mathrm{~Sv}$, i.e., a reasonable balance, where on top one has to consider that waters are transformed within the box out of the $\sigma_{\Theta}=25.0$ category into denser water mass classes, requiring a net convergence in this layer.

In the $\sigma_{\Theta}=25.0-27.3$ layer a net southward Socotra Passage outflow of $2.2 \mathrm{~Sv}$ is nearly balanced by the combined 4.2 Sv inflow through the $12^{\circ} \mathrm{N}$ section (C) minus $1.0 \mathrm{~Sv}$ outflow through the $57^{\circ} \mathrm{E}$ section (D), leaving a small net divergence of $0.8 \mathrm{~Sv}$. This has to be compared with the total absolute transports through the box boundaries in this layer of $40.5 \mathrm{~Sv}$, i.e., a very reasonable residual. Overall then the box budgets for the upper $700 \mathrm{~m}$ appear to be reasonably well closed, but the agreement of upper layer convergence versus lower layer divergence with the above water mass conversion argument can, of course, be coincidental if one consid- 
ers the large variability observed (e.g., Figure 5) over a period of more than a week that it took to carry out the observations around that box and if one considers the likely errors in the ADCP and LADCP measurements, which are of the order of a few $\mathrm{cm} \mathrm{s}^{-1}$ ([Fischer and Visbeck, 1993]).

\subsection{Response to Winter Monsoon Wind Stress}

A qualitative argument for westward inflow into the western boundary regime of the Arabian Sea in the $5^{\circ}-$ $10^{\circ}$ latitude range might be derived from the climatological wind stress forcing. The wind stress curl in winter is cyclonic over the interior of the Arabian Sea south of the axis of the Northeast Monsoon shifting to anticyclonic north of the Northeast Monsoon wind maximum off the Arabian Peninsula. The corresponding Sverdrup transport, assuming quasi-stationary response, requires a zonal inflow of $\sim 20 \mathrm{~Sv}$ between $\sim 5^{\circ}$ and $9^{\circ} \mathrm{N}$ (using Hellerman and Rosenstein [1983] winds) into the Somali Current regime, resulting in a boundary current divergence in that latitude band, which is in agreement with the northward upper layer flow in our observational area.

It is, however, questionable to what degree quasistationary response to Sverdrup dynamics is applicable in the Arabian Sea. The response mechanism is by barotropic and baroclinic Rossby waves, and what the time lag between curl variability and western boundary circulation is depends on the distance the Rossby waves have to travel to the western boundary. Because of the low propagation speeds of the baroclinic waves, it was generally assumed that there could be no quasistationary response in the off-equatorial oceans at the seasonal timescale. On the other hand, observations of the past decade in the subtropical North Atlantic did, in fact, show ([Lee et al., 1996]) that east of the Bahamas a strong seasonal boundary current cycle exists, in agreement with model studies ([Böning et al., 1991]), which is in fairly close correspondence to a quasi-stationary Sverdrup response. This was attributed to the fact that a large fraction of the response was generated in the western basin by barotropic and first-mode baroclinic waves with small time lags to the western boundary. Since our location here is close to the equator and the basin is small, quasi-stationary response might, to a substantial degree, be accomplished.

Compared to the North Atlantic case, a further complication in the western Indian Ocean might be remote forcing by waves from the Indian subcontinent ([McCreary et al., 1993]). As mentioned in the beginning, these are presumably boundary waves traveling around the Bay of Bengal and then around Sri Lanka into the Arabian Sea, where they radiate Rossby waves. On the basis of model studies it is claimed that these boundary waves are responsible for the Laccadive High during the late phase of the winter monsoon ([Shankar and
Sheyte, 1997; Vinayachandran and Yamagata, 1998]). Their most active phase appears to be at and after the end of the winter monsoon; that is, they may not interfere much with the Sverdrup setup in the early and full-blown phase of the winter monsoon period.

\subsection{Nonseasonal Variability}

There are two kinds of variability to be considered in conjunction with the interpretation of our moored and shipboard observations: intraseasonal variations of a period of a few weeks that may have caused nonsynoptic distortions during our ship survey and interannual variability that may be related to global teleconnection patterns. As far as interannual variability is concerned, it would, of course, be interesting to know how representative the winter monsoon circulations of 1995-1996 and 1997-1998 actually were of the average patterns. Inspection of the Florida States University (FSU) wind stress fields ([Legler et al., 1989]) for the Arabian Sea shows fairly small (order 20\%) year to year variations of the winter monsoon stresses. By contrast, in the equatorial zone, wind stress anomalies are of the same magnitude as the seasonal means themselves, and large interannual variations of the Equatorial Jet and Undercurrent have been reported [e.g., Reppin et al., 1999]. More observations from the northwest Indian Ocean need to become available before firm conclusions as to the interannual differences among the winter monsoons reported on here will be possible.

Regarding the energetic current fluctuations in the period range of a few weeks (Figures 4 and 5) work is still in progress as to their interpretation. One such study has determined that a large fraction of this variance during the summer monsoons of 1995 and 1996 was made by long baroclinic Rossby waves that were correlated with wind stress curl variability over the interior of the Arabian Sea (D. Quadfasel, personal communication, 1999). These were, however, fluctuations superimposed on the existing Great Whirl circulation, not those potentially responsible for its onset at the beginning of the summer monsoon. Another ongoing study investigates the instabilities of the Great Whirl as a potential energy source of shorter-period variability in the northern Somali Current regime. These results will be reported elsewhere.

\subsection{Model Comparison}

A number of studies with high-resolution numerical models have been carried out in recent years to investigate the seasonal and interannual variability of the Indian Ocean, including the Arabian Sea and its exchange with the Indian Ocean at large. Surface velocities out of the high-resolution model of Semtner and Chervin [1992] that were anaylzed by [Garternicht and Schott, 1997, Figure 2] showed a winter monsoon circulation pattern in the northwest Arabian Sea similar to what was described here on the basis of our observa- 

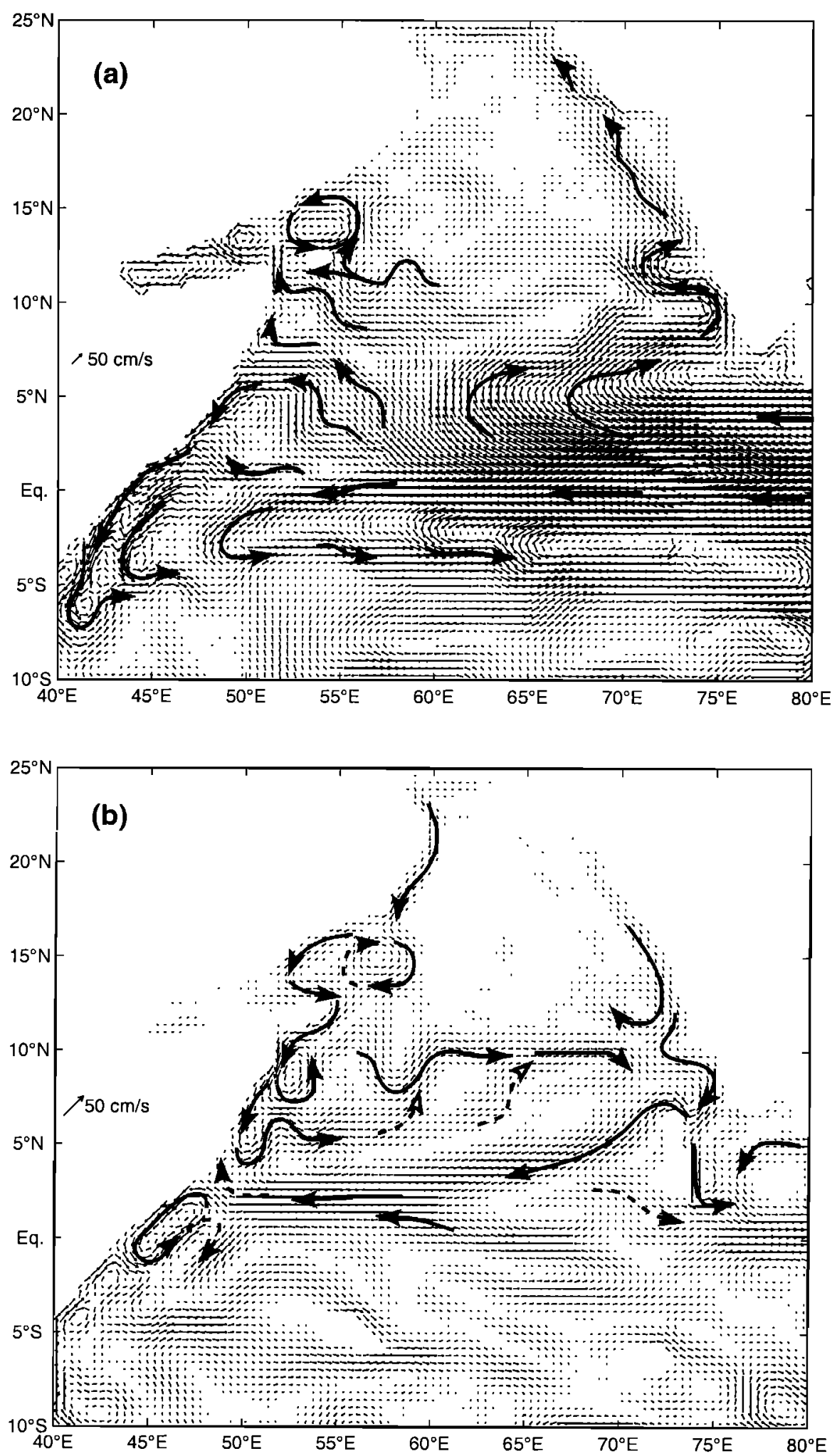

Figure 14. Monthly mean surface currents for January 1996 from the Parallel Ocean Climate Model 4 (POCM-4) (B. Semtner, personal communication, 1999) driven by daily European Centre for Medium-Range Weather Forecasts (ECMWF) operational surface winds and fluxes for the (a) surface layer and (b) undercurrent layer, 360-510 m depth. 
tions. An updated version of that model, now driven by daily operational European Centre for Medium-Range Wheather Forecasts (ECMWF) winds and fluxes, is shown in Figure 14.

Although presented as monthly mean currents, derived from a time series with three-day resolution, this model circulation is much more structured than that in the earlier version, which was driven by monthly-mean winds rather than daily winds as in the present version. Yet the general features are similar to the earlier version. The westward surface flow is most intense at low latitudes with little indication of a large-scale cyclonic circulation around the Arabian Sea (Figure 14a). At the western end, three inflow branches supply the Somali Current flow along the coast.

The main inflow, in agreement with the above Sverdrup dynamics argument, flows westward in the $4^{\circ}-$ $7^{\circ} \mathrm{N}$ latitude range. It feeds a coastal divergence with equatorward currents south of $6^{\circ} \mathrm{N}$ and a northward boundary current off northern Somalia. A second inflow branch encounters the coast just north of the equator, enhancing the cross-equatorial Somali Current transport. The northward Somali Current branch is further strengthened by a third inflow branch in the $9^{\circ}-11^{\circ} \mathrm{N}$ range. This northward boundary current exits mainly through the Socotra Passage into the Gulf of Aden. In addition, the northern inflow branch supplies northeastward near-surface recirculation around Socotra.

In the southeastern Arabian Sea the NMC flows westward between the equator and $6^{\circ} \mathrm{N}$, and part of it continues to supply the main inflow branch of the Somali Current, while part circulates anticyclonically around a large dynamic high east of $65^{\circ} \mathrm{E}$ and then recirculates northward toward the Indian coast. This ridge resembles the Laccadive High of Bruce et al. [1994] and is obtained in several model simulations already mentioned. A spinoff from that flow follows the Indian coast northwestward as one, if weak, branch of a cyclonic circulation regime, in agreement with winter monsoon observations [Shetye, 1991]. The model shows only weak currents along the northern boundary, which are westward off the NE Arabian peninsula and vanish in an eddy field farther west. The northeastward model recirculation past Socotra also vanishes into that eddy field.

At the 360-510 m level the model flow shows a southward undercurrent through the Socotra Passage and around Socotra (Figure 14b), in agreement with observations. Off India a southward undercurrent occurs in the model, again in agreement with the observations of Shetye [1991]. This undercurrent develops westward after passing the Maledives and merges in a current core that feeds into the Somali Current just north of the equator.

The southward undercurrent throughflow through the Socotra Passage and westward undercurrent inflow south of Socotra are linked upstream to a westward boundary current along the Arabian Peninsula, and downstream they merge into the Somali Current, providing Somali undercurrent inflow from a large distance. Out of the southward Somali undercurrent an eastward flow across the Arabian Sea emerges that can be traced over to India. Overall, a complicated circulation pattern results, in general agreement with the observations along the eastern and western margins.

In other models the general patterns may look different. We were shown results from the multilayer reduced gravity model of the Naval Research Laboratory, (J. Kindle, personal communication, 1999) which is driven by the actual Fleet Numerical Oceanography Center (FNOC) winds for 1997-1998, and of the Miami isopycnic model (O. Esenkov, personal communication, 1999). Both varied in many respects from Figure 14, but the main features observed for the northern Somali Current regime and reproduced in Figure 14 are present, such as general westward inflow in $6^{\circ}-10^{\circ}$ latitude band and divergence at the coast, surface outflow through the Socotra Passage and northeastward recirculation south of Socotra, and undercurrent inflow through the Socotra Passage and westward undercurrent south of Socotra. These appear therefore to be robust features of the winter monsoon circulation, but their physics require additional studies.

Acknowledgments. We thank C. Lichtenberg for his help in the current and transport analysis, M. Hamann for assistance with the graphs and critical reading of the revision, and J. Reppin for his assistance with the model fields. Financial support by the Federal Minister of Science, Education and Research (BMBF) was received under contracts 03F $0157 \mathrm{~A}$ and 03G0128A as part of the German WOCE program.

\section{References}

Böning, C. W., R. Döscher, and R. G. Budich, Seasonal transport variation in the western subtropical North Atlantic: Experiments with an eddy-resolving model, $J$. Phys. Oceanogr., 21, 1272-1288, 1991.

Bruce, J. G., M. Fieux, and J. Gonella, A note on the continuance of the Somali eddy after the cessation of the Southwest monsoon, Oceanol. Acta, 4, 7-9, 1981.

Bruce, J. G., D. R. Johnson, and J. C. Kindle, Evidence for eddy formation in the eastern Arabian Sea during the northeast monsoon, J. Geophys. Res., 99, 7652-7664, 1994.

Donguy, J., and G. Meyers, Observations of geostrophic transport variability in the western tropical Indian Ocean, Deep Sea Res., Part I, 42, 1007-1028, 1995.

Fischer, J., and M. Visbeck, Deep velocity profiling with self-contained ADCPs, J. Atmos. Oceanic Technol., 10, $764-773,1993$.

Fischer, J., F. Schott, and L. Stramma, Currents and transports of the Great Whirl-Socotra Gyre system during the summer monsoon, August 1993, J. Geophys. Res., 101, 3573-3587, 1996.

Garternicht, U., and F. Schott, Heat fluxes of the Indian Ocean from a global eddy-resolving model, J. Geophys. Res., 102, 21,147-21,159, 1997.

Hellerman, S., and M. Rosenstein, Normal monthly wind stress over the world ocean with error estimates, J. Phys. Oceanogr., 13, 1093-1105, 1983. 
Lee, T. N., W. E. Johns, R. J. Zantopp, and E. R. Fillenbaum, Moored observations of western boundary current variability and thermohaline circulation at $26.5^{\circ} \mathrm{N}$ in the subtropical North Atlantic, J. Phys. Oceanogr., 26, 962983, 1996.

Legler, D. M., I. Navon, and J. J. OBrian, Objective analysis of pseudostress over the Indian Ocean using a directminimization approach, Mon. Weather Rev., 26, 709-720, 1989.

Le Provost, C., F. Myard, J.-M. Molines, M. Genco, and F. Rabilloud, A hydrodynamic ocean tide model improved by assimilating a satellite altimeter-derived data set, $J$. Geophys. Res., 103, 5513-5529, 1998.

McCreary, J. P. J., P. K. Kundu, and R. L. Molinari, A numerical investigation of dynamics, thermodynamics and mixed-layer processes in the Indian Ocean, Prog. in Oceanogr., 31, 181-244, 1993.

Molinari, R. L., D. Olson, and G. Reverdin, Surface current distributions in the tropical Indian Ocean derived from compilations of surface buoy trajectories, $J$. Geophys. Res., 95, 7217-7238, 1990.

Murray, S. P., and W. Johns, Direct observations of seasonal exchange through the Bab el Mandab Strait, Geophys. Res. Lett., 24, 2557-2560, 1997.

Quadfasel, D., Low-frequency variability of the $20^{\circ} \mathrm{C}$ isotherm topography in the western equatorial Indian Ocean, J. Geophys. Res., 87, 1990-1996, 1982.

Quadfasel, D., and F. Schott, Southward subsurface flow below the Somali Current, J. Geophys. Res., 88, 59735979, 1983.

Reppin, J., F. Schott, J. Fischer, and D. Quadfasel, Equatorial currents and transports in the upper central Indian Ocean: Annual cycle and interannual variability, $J$. Geophys. Res., 104, 15,495-15,514, 1999.

Schott, F., J. C. Swallow, and M. Fieux, The Somali Current at the equator: annual cycle of currents and transports in the upper $1000 \mathrm{~m}$ and connection to neighbouring latitudes, Deep Sea Res., Part A, 37, 1825-1848, 1990.

Schott, F., J. Reppin, D. Quadfasel, and J. Fischer, Currents and transports of the Monsoon Current south of Sri Lanka, J. Geophys. Res., 99, 25,127-25,141, 1994.

Schott, F., J. Fischer, U. Garternicht, and D. Quadfasel,
Summer monsoon response of the northern Somali Current, Geophys. Res. Lett., 24, 2565-2568, 1997.

Semtner, A. J., and R. M. Chervin, Ocean general circulation from a global eddy-resolving model, J. Geophys. Res., 97, 5493-5550, 1992.

Shankar, D., and S. R. Sheyte, On the dynamics of the Lakshadweep high and low in the southeastern Arabian Sea, J. Geophys. Res., 102, 12,551-12,562, 1997.

Shetye, S. R., The coastal current off western India during the Northeast Monsoon, paper presented IAPSO conference, Int. Assoc. for Phys. Sci. of the Oceans, Vienna, 1991.

Swallow, J. C., and M. Fieux, Historical evidence for two gyres in the Somali Current, J. Mar. Res., 40, 747-755, 1982.

Swallow, J. C., R. L. Molinari, J. G. Bruce, O. B. Brown, and R. H. Evans, Development of near-surface flow pattern and water mass distribution in the Somali Basin in response to the southwest monsoon of 1979, J. Phys. Oceanogr., 13, 1398-1415, 1983.

Swallow, J. C., F. Schott, and M. Fieux, Structure and transport of the East African Coastal Current, J. Geophys. Res., 96, 22,254-22,267, 1991.

Vinayachandran, P. N., and T. Yamagata, Monsoon response of the sea around Sri Lanka: Generation of thermal domes and anticyclonic vortices, J. Phys. Oceanogr., 28, 1946-1960, 1998.

Visbeck, M., and J. Fischer, Sea surface conditions remotely sensed by upward-looking ADCPs., J. Atmos. Oceanic Technol., 12, 141-149, 1995.

Wyrtki, K., Oceanographic Atlas of the International Indian Ocean Expedition, 531pp., Natl. Sci. Found. Washington D.C., 1971.

F. A. Schott, and J. Fischer, Institut für Meereskunde an der Universität Kiel, Düsternbrooker Weg 20, 24105 Kiel, Germany, (fschott@ifm.uni-kiel.de; jfischer@ifm.uni-kiel.de)

(Received March 9, 1999; revised October 7, 1999; accepted October 29, 1999.) 